University of Louisville

ThinkIR: The University of Louisville's Institutional Repository

Electronic Theses and Dissertations

1947

\title{
Home Service Department, Louisville Chapter, American Red \\ Cross.
}

Sylvia Hirschfeld

University of Louisville

Follow this and additional works at: https://ir.library.louisville.edu/etd

Part of the Social Work Commons

\section{Recommended Citation}

Hirschfeld, Sylvia, "Home Service Department, Louisville Chapter, American Red Cross." (1947). Electronic Theses and Dissertations. Paper 1968.

https://doi.org/10.18297/etd/1968

This Master's Thesis is brought to you for free and open access by ThinkIR: The University of Louisville's Institutional Repository. It has been accepted for inclusion in Electronic Theses and Dissertations by an authorized administrator of ThinkIR: The University of Louisville's Institutional Repository. This title appears here courtesy of the author, who has retained all other copyrights. For more information, please contact thinkir@louisville.edu. 


\title{
UNIVERSITY OF LOUISVILLE
}

\author{
HOME SERVICE DEPARTIENT \\ LOUISVIEIE CHAPTER \\ AMERICAN RED CROSS
}

\author{
A Dissertation \\ Subritted to the Faculty \\ Of the Kent School of Social Work \\ of the \\ University of Louisville \\ In Partial Fulfillment of the \\ Requirements for the Degree \\ Of Master of Science in Social Work
}

BY

Sylvia Hirschfeld

Year

1947 
NAME OF STODENT:

TITLE OF THESIS:
Sylvia Hirschfeld

Home Service Department Louisville Chapter

American Red Cross

APPROVED BY READING COMMITTEE COMPOSED OF THE

FOLLOWING MEMBERS:

Helen A. Brown

Robert G. Warner

Mathilda Mathisen

ACTING DEAN,

Mathilda Mathisen

DATE :

June 2, 1947 
LIST OF TABLES........................... iv

LIST OF ILLUSTRATIONS.......................

INTRODUCTION................................ viii

CHAPTER

I. HISTORY OF RED CROSS AND THE LOUISVILLE PROGRAM, TO $1940 \ldots \ldots \ldots \ldots \ldots \ldots \ldots \ldots \ldots \ldots \ldots \ldots \ldots \ldots \ldots \ldots$

Development of National and International Red Cross Home Service, Louisville Chapter

American Red Cross, 1917-1940

Formation Years, 1917-1920

Legislation Affecting Home Service

Activities, 1917-1940

Volume of Cases Handled, 1918-1920

Services of the Department, 1919-1940

II. LOUISVILIE HOME SERVICE, 1940 THROUGH APRIL, 1944..34

Increase in Cases and In Assistance

Passage of Servicemen's Dependents

Allotment Act

Study of Home Service - by Ruth Haugen

Expansion of Quarters, Night and Sunday

Services

Fmergency Maternity and Infant Care Program

Change in Allotment and Allowance Act

Loans and Grants

Mustering-out Pay Bill

Use of Volunteers

III. COMMUNITY COOPERATION.

Sub-Comittee on Intake-Council of Social Agencies

Financial Relief

Case Work Services

A.E.R. Program

Problem of Legal Residence

Registration of Cases

Psychiatric Care for Veterans

Job Placement for Veterans

Where to Refer the Returning Veteran

79846 
IV. ORGANIZATION AND SERVICES OF LOUISVILIE

HOME SERVICE DEPARTHEENT.

Organization

Services

Communication and Information

Reporting

Assistance With Government Benefits

Family Service

Disaster Relief

V. PROBLEMS OF LOUISVILIE HONE SERVICE AND

COMPARISONS WITH OTHER AGENCIES............. 93

Problems.

Comparison of Services with Indianapolis and

Dayton Chapters

CONCLUSION

114

116

BIBLIOGRAPHY

127 


$$
\underline{L} \underline{I} \underline{\mathbf{S}} \underline{\mathrm{O}} \underline{\mathrm{F}} \underline{\mathrm{T}} \underline{\mathrm{A}} \underline{\mathrm{B}} \underline{\mathrm{L}} \underline{\mathrm{E}} \underline{\mathrm{S}}
$$

Table

I. Volume of Total Cases, Louisville Home Service

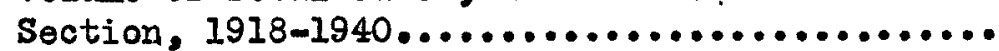

II. Some of the Causes of Visits and Applications

in Louisville Home Service Department, 1921

and $1934 \ldots \ldots \ldots \ldots \ldots \ldots \ldots \ldots \ldots \ldots \ldots \ldots \ldots \ldots \ldots$

III. Types of Cases Handled in Louisville Home

Service Department, July, 1930................

IV. Services to Men in the Armed Forces, Louisville

Home Service Department, March 1940 and March, 1941

V. Intake of Louisville Home Service Department, January, April, and October 1941, and January,

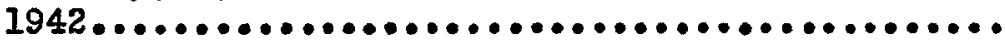

VI. Relief and Loans Given by Louisville Home Service Departnent, January, April, October,

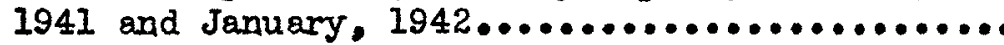

VII. Intake of Home Service Department, January through December, 1942.

VIII. Cases in Kentucky Authorized for Care Under the Bmergency Maternity and Infant Care Program, May through September 1943 00000000

IX. Expenditures for Medical and Hospital Care, Louisville Home Service Department, 1943.......

X. Expansion of Personnel, Indianapolis, Dayton, and Louisville Home Service Departments, 1941 and July, 1944........................... 109

XI. Comparison of Cases Handled by Louisville, Indianapolis, and Dayton Home Service Departments, July, 1943 through April, 1944 


\section{$\underline{I} \underline{I} \underline{\mathbf{T}} \quad \underline{O} \underline{F} \quad \underline{T} \underline{\mathbf{A}} \underline{\mathrm{B}} \underline{\mathrm{L}} \underline{\mathrm{E}} \underline{\mathrm{S}}$}

Table

XII. Comparison of Communication and Information

Services by Louisville, Indianapolis, and

Dayton Home Service Departments, July, 1943

through April, 1944.......................

XIII. Comparison of Assistance with Government

Benefits Services by Louisville, Indianapolis, and Dayton Home Service Departments, July

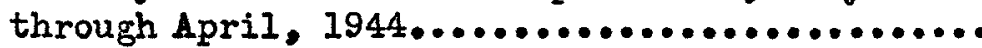

XIV. Comparison of Reporting Services by Louisville, Indianapolis, and Dayton Home Service Depart-

ments, July, 1943 through April, 1944..........

XV. Comparison of "Family Service" Services by

Louisville, Indianapolis, and Dayton Home

Service Departments, July, 1943 through April,

$1944 \ldots \ldots \ldots \ldots \ldots \ldots \ldots \ldots \ldots \ldots \ldots \ldots \ldots \ldots \ldots \ldots$ 


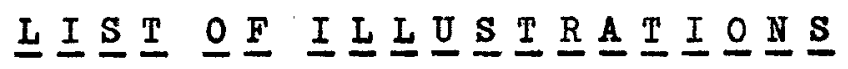

Figure

$\underline{\text { Page }}$

I.

Organization of American National Red Cross.....

73 


\section{THE C H A L L E N E OF T H E \\ RE D C R O S S C H A P T E R I H \\ WA R A N D P E A C E}

"..... To act in matters of voluntary relief and in accord with the military and naval authorities as a medium of communication between the people of the United States of America and their Army and Nary......"

The American Red Cross Congressional Charter, January 5, 1905. 
INTRODUCTION 
With the passage of the National Service Act in October, 1940, and the subsequent entry of the United States into World War II, there was an immediate call on the American Red Cross to enlarge in its function and scope to meet the growing needs of those millions of men being inducted into the Army, Nary, Marines, and Coast Guard; and to meet the needs of their dependents. The effect of these events were felt by every chapter of American Red Cross, and the country saw an immediate expansion of Home Service Departments to meet the need.

It is the purpose of this thesis to study the Louisville Home Service Department, American Red Cross; from its early beginnings in World War $I$, through the peace-time years which followed, and finally through the rapid expansion of the program as begun in November, 1940. It should be noted that accumulation of material was completed in September, 1944. This study therefore does not exemine developments beyond that date.

There is some background material, a discussion of its early development and activities, and an attempt to follow, and evaluate its activities during the peace-time years of the 1920's and the 1930's. However, emphasis has been placed on rapid expansion of the Home Service Department, following passage of the National Service Act. To what extent has the Home Service Department expanded in personnel and in services? To what extent has this expansion met the needs? What are 
the major problems which they have encountered, and how have they been solved? In its rapid rise to a major community agency, how has the Home Service Department worked with the community? How does the services rendered by the Louisville Chapter, Home Service, compare with cities of equal size and proximity to army camps? In what way have they met similar problems? What is the future of Louisville Home Service? In attempting to study and evaluate the agency, varied resources were used: as, the minutes of the Home Service Comittee, and of the Executire Committee of the Louisville Chapter; the minutes of the Sub-committee on Intake of the Councill of Social Agencies; statistics and monthly reports of the Home Service Department from its beginning through April, 1944. statistics and other information obtained from Home Service Divisions of Chapters in Indianapolis, Indiana, and Dayton, Ohio; plus much mimeographed material distributed from time to time to the staff and to the community; personal interviews with Miss Margaret Woll, Director of Home Service, Miss Elsie Mantle, Executive Secretary of the Louisville Chapter, Mrs. Louise Wood, Executive Secretary of the Louisville Council of Social Agencies, Mr. Charles A. Walter, District Supervisor of the Louisville Office of the Kentucky State Rehabilitation Service, etc; several books, a number of newspaper articles, a few periodicals, and many pamphlets; a report of Miss Ruth Haugen, Field Representative to the Louisville Chapter; and, case records 
of Home Service. The use of case material is for illustrative purposes. It is beliered that case illustrations of many of the services facilitates and increases understanding of these services, and aids in evaluating them.

It is to be noted that full cooperation was obtained with the Director of Home Service, and with the Executive Secretary of the Louisville Chapter, and the agency records were made fully available. 
CHAPTER I

HISTORY OF RED CROSS AND THE LOUISVILLE PROGRAM, TO 1940 
CHAPTER I

HISTORY OF RED CROSS AND THE LOUISVILLE PROGRAM, TO 1940 Development of National and International Red Cross

On June 24, 1859, Henri Dunant, a young Swiss, by chance became a witness of the terrible battle of Solferino, in which the French and Italians were allied against the Austrians under Francis Joseph. He saw, at the conclusion of the massacre, 40,000 dead, dying, and wounded, with no facilities for nursing care, no medical supplies, no water, or food, or shelter. During the next week he organized the townspeople, and elioited their aid in bringing help and comfort to the wounded, regardless of whether they were friend or foe; and communication with their families.

Thus was the idea of Red Cross born. Following this experience, Dunant became fired with the ambition to organize an international organization which could deal with such catastrophes. His idea was given a trial in 1863 when an international conference wet at Geneva, Switzerland, to draw up plans for his society, and in 1864 the International Red Cross Treaty was drawn up.

At this convention, the United States was represented by two "unofficial" delegates, George C. Fogg, American Minister to Switzerland, and-Charles S. P. Bowles, European agent of the

1. "History and Organization of the Red Cross," Prepared by Louisville Chapter, American Red Cross (Mimeographed). 
Sanitary Commission. When the convention adjourned Mr. Bowles submitted a report embodying the aims and text of the Treaty of Geneva to the then Secretary of State Seward, but no action was taken it. The American people, involved in a Civil War, were loath to enter into what they believed might be an entangling foreign alliance. 1 In 1869 clara Barton want abroad for travel. While in Switzerland she became acquainted with the leaders of the Red Cross movement, and was requested to try to secure on her return to America the accession of the United States to the Treaty of Geneva. In 1881 she interested President Garfield and James G. Blaine, then Secretary of State. The following yesr the Treaty was signed, and the United states became the thirty-first signatory nation. The first work of the American Red Cross was in the field of disaster relief. The organization rendered aid to victims of the Michigan forest fires in 1881, and of the Mississippi and Ohio River floods during subsequent years. The first opportunity to give aid to the sick and wounded of armies came in 1898, when frightful conditions arose in Cuba as a result of the Spanish authorities' attempt to stop civil uprising. The Central Cuban Relief Conmittee was formed. It raised funds, chartered a ship, the State of Texas, loaded it with supplies, and sent it under the Red Cross flag to Cuba.

1. Pickett, Sarah Elizaboth, The American National Red Cross; (The Century Co.. New York, 1924) Page 11. 
In June, 1900, the Red Cross Association was reincorporated by an Act of Congress. In January, 1905, a new corporation was created by Act of Congress requiring a yearly audit of Red Cross accounts be made by the War Department and provided for Federal supervision of the society through offioial representation on the Red Cross governing body. A last important step in Federal recognition of the American Red Cross was taken by President Taft on August 22, 1911, when he proclaimed:

(a) THAT, the American Red Cross is the only volunteer society authorized by this Goverment to render aid to its land and naval forces in time of war.

(b) THAT, any other society desiring to render similar assistance can do so only through the American Red Cross. 1

The purposes and powers of the American Red Cross, as organized, are:

(1) To furnish volunteer aid to the sick and wounded of armies in the time of war.

(2) For the above purposes, to perform all duties devolved upon a national society by each nation which has acceded to the Treaty.

(3) To act in matters of voluntary relief and in accord with the military and naval authorities as a medium of communication between the people of the United States and their Army and Navy, and to act in such matters between similar national societies of other govermments.

(4) To continue and carry on a system of national and international relief in time of peace and to apply this system in easing the sufferings caused by pestilence, calamities, fire, floods, 
(4) and other national calamities and to prepare and carry on measures for preventing such calamities. 1

Home Service by Red Cross Chapters was a development of World War I. It was recognized that the man in service who is not worried about his femily at home is the more effective in war duty. Military leaders in the World War were quick to give official recognition to the important influence which the morale of families had upon the morale and efficiency of the men at the 2

front. Following the entry into the war in 1917, it became increasingly evident that the fomilies of men oalled into military service needed help and guidance in orercoming the difficulties which confronted them. There was demand for accurate information as to government provisions for the men, as to regulations regarding furloughs and discharges, casualty reports, allotments of pay and government allowances, and the many other rules and procedures which applied to soldiers and their families. There arose the need to combat anxiety, to give legal protection, to safeguard health, and to promote the education and welfare of children. Financial relief was required by many families; but even greater were the calls to the Home Service workers for personal assistan ce to keep families which had been self-maintaining from becoming dependent.

1. Ibid, Page 19.

2. "The Program of the American Red Cross with the Military and Naval Services and for Disabled Veterans," Washington, D.C., May, 1936, Page 1. 
The organization for Home Service was a dual one a joint effort of the local chapters and of the National Red Cross. In army and navy stations and hospitals, overseas and at home, Red Cross field directors were assigned to duty by the National Organization. The enlisted men came to them with their worries, often when letters from home told of troubles their families were encountering. When the sick and wounded began to return from France for treatment and convalescence in American hospitals, the National Red Cross, at the request of the government, assigned to these hospitals qualified workers who supplied social service to the soldiers. The Red cross social workers in the hospitals received requests for service both from the doctors and from the patients themselves. The doctor required information giving the patient's earlier medical and social history as an aid to diagnosis and future planning. The social problems of the patient or of his family retarded his recovery, or made him too restless to remain for treatment. These problems were reported to the local Red Cross Chapters.

Each Chapter had its Home Service Section whose workers visited the family, providing servioe and necessary aid. They cooperated with the patient add with the field director or hospital social worker in outlining and carrying through a social plan for the welfare of the man and his dependents. Urgent problems also grew out of the migration of soldiers' families to comunities adjacent to the cantonments in this country. The National Organization placed special Home Service workers at such points. 
Thousands of families who were stranded or otherwise in trouble were helped with shelter, food, medical care and transportation back home.

At the close of the war there were 30,000 Home Service workers, of whom 28,000 were volunteers, carrying on this work throughout the United States for service men's families. It was claimed that this service reached every city, town, village and rural section. It became a fundamental part of the Red Cross program, in great measure mitigating the sufferings of war and aiding in the task of human reconstruction.

By the end of World War I, the organization of the American Red Cross consisted of: a General Board; a Board of Incorporators; a Central Committee; a National Headquarters and Division administration staff; and local chapters. The General Board consisted of the Central Comittee; of members of the Board of Incorporators, a self-perpetuating body of sixty-five persons; of members of certain national comittees, and of delegates from chapters to Red Cross annual meetings. It met annualy and its function was to hear and accept the annual report of the society and discuss matters of interest pertaining to its work. The annual report was then submitted to the Secretary of War for an audit of receipts and expenditures, and transmitted by him to Congress and published. 
The Central Committee, functioning as the governing body of the Red Cross, consisted of eighteen members, six of whom were elected by the Board of Incorporators, six appointed by Chapters, and the other six appointed by the President of the United States; the latter to include the chairman of the Contral Committee and a representative each from the Department of State, War, Navy, Justice, and the Treasury. The President of the United States was designated as president of the American Red Cross. The Central Committee was to meet at the call of its chairman, and its vote of approval was necessary for the initiation and conduct of all American Red Cross activities and the expenditure of all American Red Cross funds. To attend to the detail of these activities, an Executive Committee of nine members was appointed from its membership.

Functioning under the direction of the chairman of the Central Committee, the National Headquarters was charged with the operating responsibility of the Red Cross program. It consisted of the chairman, vice-chairman, and their associates. These vice-chairmen were the Vice-Chairmen in Charge of Domestic Operations and the Vice-Chairmen in Charge of Foreign Operations. Under the Vice-Chairmen of Domestic Operations was the Division of Chapter organization and the various types of service which the Red Cross was authorized to conduct in the United States. The Division organization was the link between National Headquarters and the local Red Cross Chapters, 
each Division officer consisting of a manager and his staff. During the war there were fourteen divisions, but at the close of operations these were reduced to six.

The local unit of Red Cross was the Chapter. Its responsibility was for all local Red Cross activities within its territory, subject to the policies and regulations of the National Organization as enumerated by the manager of the Division within which the chapter was located. The territory assigned to a chapter was usually a county, and its members the residents of the county who became members of the Red Cross through the yearly payment of membership dues. The governing body of the chapter was the chapter Executive Committee, to be elected by its members. HOME SERVICE, LOUISVILLE CHAPTER, AMERICAN RED CROSS, 1917-1940

Formation Years, 1917-1920

On March 24, 1917, authority to form a Louisville Chapter was given by the Director of the Central Division, Chicago, Illinois. The Louisville Chapter received its charter on April 3, 1917. It certified that "the Louisville Chapter, having jurisdiction over that territory in the State of Kentucky specifically defined in the authority to organize the Chapter heretofore issued, has been regularly organized and is authorized and obligated to engage in Red Cross activities in conformity

1. Pickett, Sarah Elizaboth, The American National Red Cross.

(The Century Co., New York, 1924) Page 25. 
with the policies and regulations prescribed and to be prescribed by the Central Committee at Washington."

Mr. F. M. Sackett was chosen as a temporary chairman, with an acting temporary comittee of twenty-five members of the community. These men were to act merely as organizers of the Chapter. On March 29, 1917, the committee met to establish the permanent organization. Officers chosen at this time were: R. C. Ballard Thurston, Chairman; Mrs. Helm Bruce, Vice Chairman; Oscar Fenley, Treasurer; and W. E. Morrow, Secretary. The Chairman appointed an Executive Committee of five members, with the Chairman and Secretary ex-officio members. 1

As stated in the By-Laws, the Board of Directors was given all powers of govermment, direction, and management of the Chapter and was to meet annually. An Executive Committee was provided for to have charge of the affairs of the Chapter between sessions of the Board of Directors. A committee was appointed to have charge of all military relief operations of the Chapter, to be entitled the Section for Military Relief. A second committee was appointed to direct the civilian relief activities, to be entitled the Section for Vivilian Relief (later renamed Home Service).

The subject of training workers for Civilian Relief was first introduced at the Executive Cormittee meeting of April 27, 1917. It was stated that the idea had been conceired during a New Albany tornado, when many volunteers for help were 
available, but there was no one to direct the work until trained Red Cross workers came from Chicago and Indianapolis. It was suggested that a class of instruction be given under the auspices of Red Cross, in which noted relief workers were to speak. It was further suggested that some field work be given, with special reference to the dependent families of soldiers. The Executive Commitioe unanimously roted for acceptance of this planning, and the concept of trained workers for Civilian Relief 1 became a part of the program.

On June 7, 1917, the first permanent building for Red Cross headquarters was chosen, at 619 South Fourth Street。 The following month Miss Harriet Anderson was selected as a competent person to direct Civilian Relief. Her office was to be located at headquarters, her title, Secretary of the Committee on Dependent Frmilies. By September, 1917, Miss Anderson reported to the Executive Committee that she and her seven volunteer assistants had made 143 visits to families of enlisted men. The most-frequent request made by families during this period was for the assignment of pay by the servicemen to his femily. These received attention, either through correspondence with Washington, or in the case of soldiers stationed at Camp Taylor, Kentucky, by direct contact with the officers at the post. By December, 1917, the volume of service had increased to such an extent that the appointment of an assistant to Miss Anderson was 
approved.

In February, 1918, the following statement was made

by Miss Harriet Anderson to publicize the activities of

Civilian Relief:

The Civilian Relief Department of Louisville Chapter, American Red Cross was qpened August 1, 1917. This department concerned itself with families of enlisted men and has at its disposal sufficient funds from the general treasury of the Louisville Chapter to provide adequately for those in need of any financial help. This branch of American Red Cross will be increasingly important because the morale of the Arry depends somewhat on the attitude of mind of the families left behind. A man is a poor soldier if he knows his family is unprovided for.

Much attention has been given up to this time to the arranging of allotments from enlisted men to their families. The War Risk Insurance Law provides for all relatives of men in the service. Compulsory allotments are to provide for the wife and children, voluntary allotments for all other relatives.

The Civilian Relief Department has been called upon by hundreds of people to give informetion regarding operation of the law. Because of congestion in the Treasury Department in Washington few families have received allotment checks. The money which has been loaned given to families is due chiefly to delay in payment from the government. 1

As previously stated, the war-time duties of Home 2

Service section were directed towards three groups: the

1. "The Community," published by the Louisville Bederation of Social Agencies, Louisville, Kentucky, February, 1918.

2. By November, 1918, Civilian Relief had been renamed Home Service Section. 
serviceman, his dependents, and discharged servicemen. In November, 1918, with the signing of the Armistice, it was recognized that the community would be faced with the problem of planning for the returning veterans. In its Annual Report, Home Service stated that:

In addition to the work heretofore conducted by the Home Service section, new work has constantly been put upon it and meny new developments may be expected during the period of demobilization. For example, the War Department has asked Red Cross to undertake an important part in the reintroduction into the industrial community of disabled soldiers. We may therefore expect an increase rather than a diminution of the work of this department during the coming year. 1

The Home Service Comitter, acting in an advisory capacity to the Home Service Division, was organized January 17, 1919. It was immediately concerned with the Distribution of leaflets to the families of the 245 Louisville casualties giving information regarding matters of arrears of pay, insurance, and so on; with the problem of families having men in service who made no provisions for their support; and with the adoption of a relief budget. Their concern in this matter was primarily that Louisville Chapter's policy of financial assistance remain in accord with that of cities of similar size.and proximity to army camps; and in working towards such a policy, obtained figures of relief expenditures from such similar cities.

1. Annual Report, Home Service Section, November 20, 1918.

2. Minutes of Home Service Committee Meeting, February 7, 1919. For the purpose of brevity, all further references to Home Service Comittee Meeting minutes will be designed as "minutes." 
It is interesting to note that by the middle of 1919 ,

many persons were asking the question, "How much longer will

the work of Home Service oontinue?" In a letter from the

Secretary of Home Service to the Chairman of the Louisville

Chapter, it was stated:

In reply to your question as to how much longer I feel the work of Home Service will continue, I cannot answer. I believe the discharge of the 1700 men belonging to the First Division just arrived at Camp Taylor will about complete the discharge of drafted men from this district.

For a long time the discharge from Camp Taylor was so much more rapid than it was possible for the re-employment of the men, that this alone will be a contributing cause for the need of Home Service for some months. Not that Home Service must secure employment (this is handled by the American Legion) but Home Service often has to render finencial aid to the family between the time of discharge and the date of employment.

Again, after the first heavy discharge began, Home Service was only able to render emergency assistance in a great percent of the cases handled. Now that the man has been discharged, we must retrace our steps and not close any case until we can say that all Government obligations have been received and the family standard has not been lowered because of the man's time in service.

In actual figures there is not a great increase in cases, but the services asked require more careful handling and much more time. Each day brings an increase in the number of men discharged with a mental or physical disability, which require a good deal of time for adjustments. 1

1. Anmual Report Home Service Section, Ootober, 1920, to October, 1921. 
In retrospect, how strange it seems that anyone should believe the work of Home Service would be nearly finished just one year following World War I.

Legislation Affecting Home Service Activities, 1917-1940

The author cannot include all the acts passed by Congress in regard to servicemen, veterans, and their dependents, ${ }^{1}$ but because of their direct bearing on Red Cross activities during this period, will touch on the most importent of the acts. On October 16, 1917, Congress passed an important amendment to the War Insurance Act of 1914. Among the provisions of the emendment were:

The allotment of pay (of all enlisted men in the military and naval forces of the United States) shall be compulsory as to wife, a former wife to whom alimony has been decreed, and a child, and voluntary as to any other person. Class A rates are: (a) If a wife but no child, $\$ 15$; (b) If a wife and one child, \$25; (c) If a wife and two children, $\$ 32.00$, with $\$ 5.00$ per month for each additional child; (d) If there be no wife but one child, $\$ 5.00 ;(\theta)$ If there be no wife but two children, $\$ 12.50$; (f) If there be no wife but three children, $\$ 20.00$; (g) If there be no wife but four children, $\$ 30.00$, with $\$ 5.00$ per month for each additional child.

Class $B$ allotment rates are: (a) If there be one parent, $\$ 10.00$; (b) If there be two parents, $\$ 20.00$; (c) For ch grandchild, brother, sister, and additional parent, $\$ 5.00$. Family allowances for members of Class $B$ shall be granted only if the member is dependent in whole or in part on the

1. This information may be obtained from "Laws Relating to Veterans," compiled by Elmer A. Lewis (U.S. Government Printing office, Washington, 1944)。 
onlisted mas.

The Wer Department or Navy Department shall grant insurance agai nst the death or permanent disability of (every commissioned officer or enlisted man) in any multiple of $\$ 500.00$, and not less than $\$ 1,000$ or more than $\$ 10,000$, upon the payment of the premiums, as provided. During the period of war and thereafter until converted the insurance shall be term insurance for successive terms of one year each. Not later than five years after the date of termination of the war, the term insurance shall be converted, without medical examination, into such form or forms of insurance as may be required by regulations and as the insured may request. 1

Further provisions of the law provide for compensation to the widow or child, or the widowed mother, if death resulted from personal injury suffered or disease contracted in the line of duty. It also provided for compensation to the veteran, wife and child, and, or dependent widowed mother, if the veteren was disabled in the line of duty.

On June 27, 1918, Congress passed the Vocational Rehabilitation Act, to provide for vocational rehabilitation and return to civil employment of disabled persons discharged from the a rmed forces of the United States. It stated that:

Every person who is disabled under the circumstances entitling him, after discharge from the military or naval forces of the United States, to compensation under -.. the Act to authorize the establishment of a Bureau of WarRisk Insurance in the Treasury Department (October 6, 1917), and who, after his discharge, in the opinion of the board, is unable to carry on a gainful occupation, to resume his former occupation, or

1. "Laws Relating to Veterans," compiled by Elmer A. Lewis (U.S. Government Printing Office, Washington, 1944) Pages 10-24. 
to enter upon some other occupation, ... shall be furnished by said board, where vocational rehabilitation is feasible, such course of vocational rehabilitation as the board shall prescribe and provide.

Every person electing to follow such a course of rocational rehabilitation shall, while following the same, receive monthly compensation equal to the amount of his monthly pay for the last month of his active service, or equal to the amount to which he would be entitled under the Act (above mentioned) whichever amount is the greater. If such person was an enlisted man at the time of his di scharge, for the period during wich he is offered a course of rehabilitation, his family shall receive compulsory al lotment and fanily allowance ... in the same manner as if he were an enlisted man. I

On August 9, 1921, an act was passed establishing an

independent bureau under the President of the United States to be known as the Veterans Bureau,

the director of which shall be appointed by the President, by and with the advice and consent of the senate. The powers and duties pertaining to the office of the Direotor of the Bureau of War Risk Insurance now in the Treasury Department are hereby transferred to the director, subject to the general direction of the President. The director shall establish a central office in the District of Columbis, and not more than fourteen regional offices ana suoh sub-offices as may be deemed necessary. 2

On May 19, 1924, the World War Adjusted Compensation Act was passed. It provided a pay adjustment or "bonus" for veterans of Torld War I. Excerpts from the law stated:

The amount of adjusted service oredit shall be

1. Ibid, Pages 35-38.
2. Ibid, Pages $72-73$.


computed by allowing the following sums for each day of active service in excess of sixty days, in the military or naval forces of the United States after April 5, 1917, and before July 1, 1919, as shown by the service or other record of the veteran; 1.25 for each day of overseas service, and $\$ 1.00$ for each day of home service; but the amount of the credit of a veteran who performed no oversea service shall not exceed $\$ 500.00$, and the amount of the credit of a veteran who performed any oversea service shall not exceed $\$ 625.00$.

This sall be paid to each veteran in addition to any other amounts due such veteran in pursuance of law, the amount of his adjusted service credit, if, and only if, such credit is not more than $\$ 50.00$. If the amount of his adjusted service credit is more than $\$ 50.00$, there (will be) issued a non-participating adjusted service certificate of a face value equal to the amount in dollars of 20-year endowent insurance that the amount of his adjusted service credit increased by 25 per centum would purchese, at his age on his birthday mearest the date of the certificate, if applied as a not single premium, calculated in accordancew ith accepted actuarial principles and based upon the American Experience Table of Mortality and interest at 4 per centum per annum, compounded annually. The veteran shall name the beneficiary of the certificate ... The amount of the face value of the certificate shall be payable (1) to the reteran twenty years after the date of the certificate, or (2) upon the death of the veteran prior to the expiration of such twenty-year period, to the beneficiary nemed. 1

On June 7, 1924, the World War Veteran's Act was passed. This act was to consolidate, codify, revise and reenact the laws affecting the establishment of the U.S. Veteran's Bureau and the administration of the War Risk Insurance Act, and the Vocational Rehabilitation Aot。 It designated Red Cross as an agency authorized to assist veterans in the preparation and prosecution of their claims, by stating: "No olain agent or attorney except the recognized 
representatives of the American Red Cross, the American Legion, the Disabled American Veterans, and the Veterans of Foreign

Wars and such organizations as shall be approved by the Director, shall be recognized in the presentation or adjudication of claims..."

Some revisions made by the Act, and highlights of it follow:

For death or disability resulting f'rom personal injury suffered or disease contracted in the military or naval service on or after April 6, 1917, and before July 2, 1921, or for an aggravatinn or recurrence of disability existing prior to examination for service, when such aggravation or recurrence was caused by military or naval service on or after April 6, 1917, and before July 2, 1921, by any commissioned officer or enlisted man .... the United States shall pay to such (veteran) or dependents, compensation as herein provided. 2

If death occur or shall have occurred subsequent to April 6, 1917, and before discharge or resignation from the service, the United States shall pay for burial expenses .... a sum not to exceed $\$ 100.00$. Where a veteran of any war dies after discharge and does not leave sufficient asseits: to meet the expenses of his burial .... the Veteran's Bureau shall pay a sum not exceeding $\$ 100.00$.

The Veteran's Bureau shall provide hospital, dental, medical, surgical, convalescent care and treatment, and prosthetic appliances for any member of the military or naval forces of the United States, not dishonorably discharged, disabled by reason of any wound or injury received or disease contracted .... while in the active military or naval service of the United States on or after April 6, 1917, and before July 2, 1921.

Any person now receiving a gratuity or pension from

1. Ibid. Page 120.

2. For rates of compensation, see "Laws Relating to Veterans" compiled by Elmer A. Lewis, (U.S. Government Printing Office, Washington, 1944). 
the United States under existing law shall not receive compensation under this (lew) unless he first surrenders all claim to further payments of such gratuity or pension.

The United States, upon application, shall grant insurance against the death or total permanent injury (of officers and enlisted men) in any multiple of $\$ 500.00$ and not less than $\$ 1,000.00$ or more than $\$ 10,000.00 \ldots$ Not later than July 2, 1926, all term insurance held by persons who were in military service after April 6, 1917, shall be converted, without medical examination, into such form or forms of insurance as prescribed by regulations and as the insured may request. (Ordinary life, twenty-payment life, endowment, etc).

Vocational training provided (by this act) shall be granted to persons entitled only where application: has been made on or prior to June 30,1923 . No vocational training shall be granted or continued to any person whatsoever after June 30,1926 , and no training allowance shall thereafter be paid to any persor. 1

On March 30, 1933, Congress passed the Economy Act, re-

ducing veteran's compensation, "in order to maintain the credit of the United States Government." It stated that:

All public laws granting medical or hospital treatment, domiciliary care, compensation and other allowancos, pension, or retirement pay to veterans and dependents are hereby repealed. The Veteran's Bureau shall immodiately cause to be revived all allowed claims under the above referred to laws and where a person is found entitled under the act, authorize payment or allowance of benefits in accordance with the provisions of this Act.... The minimum and maximum monthly rate of pensi on which may be paid for death or disability shall be as follows: For disability, from $\$ 6.00$ to $\$ 275.00$; for death, from $\$ 12.00$ to $\$ 75.00$.2

1. Ibid. Pages 114-139
2. Ibid. Pages 260-268


Other acts passed, affecting the program for veterans and their dependents were the act of June 29, 1934, to liberalize widow' and childrens' pensions, the Gold Star Mother's Act, of August 16, 1937, to liberalize provisions of existing laws governing service-connected benefits for World War veterans and their dependents, the act of May 13, 1938, further liberalizing benefits for widows and dependent children of World War veterans, the act of July 19, 1939, again an aot of liberalizing benefits, and the act of August 4, 1939 .

The June 28, 1934, act provided that:

The surviving widow, child, or children of any deceased person who served in the World War before November 12, 1918, who, while receiving or entitled to receive compensation, pension, or retirement pay for 30 per centum disability or more directly incurred in or aggravated by service in the World War, dies or has died from a disease or disability not service connected, shall be entitled to receive compensation. 1

The Gold Star Mother's Act increased the rates of death compensation due to dependents of a World War veteran who died as a result of an injury while in service. It also provided that if at the time of the veteran's death he was entitled to receive or was receiving compensation, pension, or retirement pay for 20 per centum disability, the dependent was eligible for compensation if the veteran's death resulted from a disense or disability not service connected.

The Act of May 13, 1938, stated that dependents were eligible for compensation "if the veteran's death resulted from a 
disease or disability not service-connected, and at the time of the veteren's death he was receiving, or entitled to receive compensation, pension, or retirement pay for 10 per centum dis1 ability." The Act of July 19, 1939, increased the monthly rates of compensation payable to dependents of deceased veterans. Finally, the Act of August 4, 1939, provided pensions to nembers of the Regular Army, Navy, Marine Corps, and Coast Guard who became disabled by reason of their service, equivalent to 75 per cent of the compensation payable to war veterans for similar service-connected disabilities.

$$
\begin{gathered}
\text { Volume of Cases Handled, } 1918 \text { - } 1940 \\
\text { Table I }
\end{gathered}
$$

Volume of Total Cases,

Louisville Home Service Department, 1918 - 1940

\begin{tabular}{lr|rr}
\hline YEAR & CASES & YEAR & CASES \\
\hline 1919 & 12,441 & 1930 & 6,245 \\
1920 & 12,059 & 1931 & 8,558 \\
1921 & 11,262 & 1932 & 6,350 \\
1922 & 9,943 & 1933 & 5,127 \\
1923 & 6,470 & 1934 & 5,366 \\
1924 & 4,731 & 1935 & 4,700 \\
1925 & 5,068 & 1936 & 2,825 \\
1926 & 3,584 & 1937 & 759 \\
1927 & 4,120 & 1938 & 1,018 \\
1928 & 4,117 & 1939 & 1,998 \\
1929 & 4,689 & & \\
& & & \\
\hline
\end{tabular}

* From Annual Reports, Hone Service Section, 1919 through 1939. As indicated by Table I, the cessation of World War I did 
not bring about a sudden drop in case load. There was only a 9 per cent decrease in the total number of cases handled in 1921, over that handled in 1919.

The first sizable drop in the case load following World War I was seen in 1922, and 1923 and 1924 saw a continued decrease in cases handled. In 1925, there was an increase of 7 per cent of total cases, as the result of the passage of the "bonus" act. A second reason for this increase was the closing in April, 1924, of the New Albany, Indiana, Chapter of American Red Cross, due to lack of funds. Executive Committee action approved the referral of ex-service mon from that area needing counseling and assistance with claims to the Louisville Chapter. 1 By 1929, the case load was again seen to be rising, and at its annual meeting in october, 1929, the chairman of Home Service reported that the work of the department was becoming greater rather than lessening.

Explanation for the rising case load may be found in

a letter written in January by Mr. Don. C. Smith to all Home

service Secretaries. He stated that:

On April 2, 1928, the Director of the United States Veterans Bureau in a letter to the Director of War Service, American Red Cross, wrote 'The continuation of this service (by Red Cross) of assisting claimants in presenting their claims under the World War Adjusted Compensation Act and the World War Veteran's Aot is greatly needed and will be appreciated by this Bureau.' In its pre-

1. Executive Committee Minutes, Loui svilıe Chapter, American Red Cross, April, 1924.

2. Executive Comittee Minutes, Loui sville Chapter, American Red Cross, October, 1929. 
vious pronouncements the Central Committee

has taken the position that the Red Cross stands committed to a program of service to the disabled veteran and his dependents; that this service consists of assistance to the reteran in the preparation and presentation of claims for benefits granted by the Congress of the United States and in addition to such claims service includes temporary relief where necessary for the veteran or his dependents during the adjudication of the claim by the government when a disablility originating in war service is the basis of the clain. It is the sense of the Central Committee that this is the proper and logical position for the Red Cross to take respecting its obligations to the disabled veteran and it re-affirms its policy.

...This service is an obligation to whioh the Red Cross stands comitted and all chapters are urged to provide sufficient funds for its maintenance and to put forth every effort to see that it is adequately rendered. We are reminded that the peak of the load for the mentally disabled will not be reached before 1947, according to a recent estimate made by the Director of the Veteran's Bureau. Chapters are daily finding veterans who have never filed claims, or dependents who have not known of the rights resulting from the death of men in service or thereafter. 1

The work of Home Service in assisting veterans promised, in 1929 , to be a program of long duration.

The increase in cases for 1930 and 1931 seems to verify the atatements in 1929 of the future of Home Service activity. Again in 1932 and 1933 there was a decrease in cases, but in 1934, when Congress passed the act providing for compensation to widows and children of World War veterans whose death was not due to war service, there was an immediate increase in intake. In making his report at the Annual Meeting of Red Cross in January, 1935, the Home

1. Letter from Don C. Smith, Di rector of War Service, American Red Cross Headquarters, to all Home Service Secretaries, January 19, 1929. 
Service Chairman stated that "increased service during the past year has been due to the passage of the act of June 28, regarding veteran's benefits." Total eases in 1937 reached its lowest level. This was due largely to the decrease in number of disability claims. At last most veterans of World War I had filed their claims, and were being cared for. There was now a shift of emphasis as cases of dependents of deceased men became more numerous. This group accounted for most of the cases during the year. A lesser reason for the decrease in case load was the Louisville flood of 1937. During the flood period, the Home Service staff gave an indeterminate amount of time to Disaster Service. The flood produced a general upheavel in the city, and emphasis was pleced on allieviating the distrees of those affected. All financial assistance and case work services given during this period were under the organization of the Disaster Relief Committee, Louisville Chapter, American Red Cross. This committee was in authority during the emergency period, and its work obtained precedent over any other local welfare group. In 1938, legislation again effected an increase in total cases handled. This legislation was the increased benefits to widows and children of World War I veterans. 1939 saw the passage of several additional veterans acts, thus increasing Home Service Claims activitios, and causing an accompanying increase in case 1oad.

1. Executive Comittee Minutes, Louisville Chapter, American Red Cross, January 16, 1935. 
Services of the Department, 1919-1940

As stated in the 1921 Loui sville Social Service

Directory, Home Service was then "particularly directed towards disabled men in hospitalization, compensation, vocational training, and insurance adjustments." ${ }^{1}$ For the disabled man, the war did not end with the Armistice. Men came back to confinement in hospitals, and to long months of voaational training arranged for by the government for those so seriously disabled that they could not return to pre-war occupations. Many times, family problems were detrimental to the recovery of the veterans and Home Service workers were called upon for assistance.

Every veteran with a disability caused by military service had a potential claim against the government for hospital or medical treatment, compensation or pension and often other benefits. Dependents of veterans who died as a result of service disability had similar rights. To secure these rights exact legel and medical proof was required. Because of the technicalities of the law and the complicated forms to be filed, very few persons could prepare their claims without assistance. The Red Cross was designated by law in the World War Veterans Act as an agency authorized to assist veterans in the preparation and prosecution of their claims. This claims service was accepted as a function of Home Service, and accounted for much of its work during the peace-time years of the 20's and 30 s. At its meeting in February, 1920, the Home Service Committee

1. "1921 Louisville Social Service Directory," Louisville Community Council, 1921. 
recognized its responsibility to the veteran, and it was decided that a form letter be mailed to all 12,587 ex-servicemen of World War I in Louisville and Jefferson County, explaining the government's obligation towards them, and offering the service of American Red Cross of assistance and counseling. Men who served in World War I were protected by "War Risk Insurance," which was later converted into other forms of insurance. The majority of World War I veterans dropped their insurance, after leaving the service. Some, however, kept theirs in force, and others who were able to pass the required health examination, were permitted to purchase United States Government Life Insurance. Home Service was available for advice and assistance with applications in such cases.

During the period of preparing and prosecuting a veteran's claim, the Home Service accepted responsibility for such social service as the Veteran and his family might need. The prosecution of a claim often entailed months of work. Financial relief during that time meant at times a full household budget for a family absolutely destitute, or perhaps only a small amount in the form of a loan to assist them until the first government check was received. Such services made up a large part of the peace-time case load of the Home Service Department. We cite a case of $\mathrm{Mr}$. F., a disabled veteran receiving care in the Veteran's hospital, at Washington, D.C.

In January, 1920, the feteran's mother applied for assistance with transportation and the necessary living expenses in order to visit her son. Correspondence 
with the Veteran's Hospital indicated the desirability of such a visit, and railroad fare plus money for maintenance was given the mother. After several months, the veteran was discharged from the hospital and returned to Louisville. He was found to be extremely nerrous, emotionally upset, and unable to adjust to employment. He was immediately assisted in filing a claim for government benefits, and was given financial assistance for himself and mother. Meanwhile, the veteran was directed to a program of Vocational Rehabilitation, and the case remained active until the veteran had begun to receive government benefits.

In another situation, Mr. R., a veteran was discharged from the army on Febmury 12, 1919, and died five days later of pneumonia. According to the family, he had contracted pneumonia, pending discharge, but had failed to report it to the military authorities. He had become seriously ill after arriving home and had died. His dependent father obtai ned Home Service assistance in filing for accrued government insurance based on his son's service. The benefits were soon received. Some time later, the soldier's step-mother applied for assistance with death benefits. She was considered the preferred claimant as she fulfilled the requirement of having been married to the veteran's father one year prior to the death of the veteran. In completing the application, it was learned that Mrs. R. had been previously married, and that her first husband had died in Lithuania. In order to obtain proof of his death, the interviewer instigated correspondence with National Headquarters, American Red Cross, requesting that the American Counsel in Lithuania obtain this death certificate, and return it in a document bearing his authentification. This information was obtained, the application completed, and Mrs. R. began to receive her payments. 1

Although by 1922 the country had fully returned to a peace-time basis, and the majority of veterans had returned home, bringing to Home Service their many problems, there was still maintained the permanent peace-time army. The record of personel service rendered during the war to soldiers, sailors, and marines, affirmed the fact that increased military efficiency resulted from 
the adjustment of personal worries. It was therefore

recognized that men in the peace-time Army and Navy and their

families, also, had their social problems. The prompt solution

of these problems, along with its military value, was of far-

reaching social and economic value to the man's family and to the

community in which the family lived. Home Servico accopted re-

sponsibility in such cases. Communication with Field Directors

in Army, Nary, and Marine Corps posts, in the matter of discharge

and furlough investigations, dependency discharges, medical and

social histories, and varied needs for case work services, became

a part of the function of the Louisville Chapter during the peace-

time years which followed. The volume of such service was small,

however, compared with the total volume. In 1922, of 9,943 cases

handled, only 183 were of active service.

To illustrate one type of the above service, we cite the case of Pvt. S., who made application at his army post for dependency discharge because of the dependency of his mother, Mrs B. The Field Director at his post communicated with Home Service, and a social worker visited in the home of the soldier's mother. The social worker learned that at the time of the soldier's enlistment, his mother and step-father were maintai ning their own home, and support had been adequate. However, the step-father had recently deserted, leaving Mrs. Bo with no means of support. Mrs. B. had applied for assistance at the public agenoy, but was denied because she was beliered to be able to do light work. The visitor learned that Mrs. Bo found it impossible to obtain the type of work she was physically able to do; that she was emotionally unstable; that she was very upset over the desertion of her husband; and that she was unable to adjust to living alone. The visitor verified that in the event of a discharge the soldier would obtain employment in a factory in Dayton, Ohio. The visitor incorporated her findings in a Home Conditions report which she returned to the Field Director, and within one month the soldier was given a Dependency Discharge. 1 
It is to be emphasized that the military authorities had accepted the case worker's findings and acted accordingly• In May, 1925, the Red Cross worker stationed at the Marine Hospital, Louisville, was withdrawn. Since 1919, a full-time worker had been maintai ned at the Marine Hospital. Through this social worker, Home Service had proved to be the connecting link between the hospital and the patient's home chapter. In all cases where the patient was at the Marine Hospital for a week or more, the worker communicated with the home chapter, giving the diagnosis and advice for future care, If the rocational officer had been consulted, his recomendations for the future were included in the letter. In all cases, requests were made that the patient's home be visited so that cooperation and planning with the family might be obtained for the best possible future of the patient. The worker at the Marine Hospital was a member of the Home Service staff. As such, she was required to report at Home Service headquarters each day, to attend weekly staff meetings, and in all ways keep in close touch with general Home Service activities. By May, 1925, it was believed that daily service was no longer needed, and the worker was withdrawn. In her place, a worker was instructed to make a visit once a week to render whatever assistance was needed by the patients. Durine this period, scheduled visits were also made to Lakeland, Waverly Hills, and Hazelwood Sanitarium to assist in writing letters to the families of patients and to assist in filing their claims. 
Following the passage of the World Was Adjusted Compensations Act, a full-time worker was maintained for a short time at the American Legion to assist in filing for the Bonus, and in requests made for other types of service.

\section{Table II}

Some of the Causes of Visits and Applications in

Louisville Home Service Department, 1921 and 1934.

\begin{tabular}{l|r|r}
\hline VISITS AND APPLICAIIONS & 1921 & 1934 \\
\hline Compensation Claims & 3950 & 3066 \\
Allotments and Allowances & 2050 & 0 \\
Information Only & 1313 & 1298 \\
Vocational Training & 962 & 0 \\
Medical Aid & 506 & 179 \\
Discharge From Service & 368 & 15 \\
Insurance Claims & 364 & 136 \\
Arrears of Pay & 272 & 0 \\
Loans & 258 & 19 \\
Relief & 243 & 25 \\
Government Bonus & 228 & 292 \\
Liberty Bond Applications & 158 & 5 \\
Discharges Lost & 148 & 269 \\
Burial Expenses & 128 & 133 \\
Pensions & 127 & 211 \\
Applicants Seeking Employment & 115 & 575 \\
State Bonus & 87 & 115 \\
Emergency Conservation Work & 0 & 504 \\
Transients Seeking Assistance & 0 & 156 \\
Miscellaneous * & 415 & 495 \\
& & \\
\hline
\end{tabular}

* Miscellaneous cases include: In 1921, Travel Pay, Dental Treatment, Transportation, Gravestones, Missing Men, Victory Medals, Clothing Claims, Desertion Cases, Duplicate French Citations, Unolaimed Checks Located; each of which did not reach a total of 100 applications. In 1934, miscellaneous cases included Missing Men, Death Certificate, Birth and Marriage Certificate, Civil Service Application, Gravestone Applications, Civil War Pensions, Indian Pensions, Slave Pensions, Confederate Pensions, Medal Applications, Claim Cases Appealed, Workman's Compensation Applications, Old Age 
Pensions; each of which did not reach a total of 100 applications.

Table II indicates the comparisons and changes in types of services given immediately following World War I, and the changing needs thirteen years later. The major service in both years was for assistance with obteining compensation for the veteran and his family. Howerer, whereas in 1921, there were a great number of applications for help with allowances and allotments, in 1934 the war was too far removed for such a need. In its place appeared the need for sebvices to the veteran and his family to combat the economic effects of the depression.

\section{Table III}

Types of Cases Handled in Louisville Home Service Department, July, 1930.

\begin{tabular}{l|c|l|c}
\hline \hline MAJOR-CARE CASES & NUMBER & MINOR-CARE CASES & NUMBER \\
\hline None & 0 & $\begin{array}{l}\text { Advico or Referral } \\
\text { only } \\
\text { Investigations } \\
\text { for Out-of-Town } \\
\text { Agencies } \\
\text { Government Paper } \\
\text { Work (Claims) }\end{array}$ & 114 \\
\hline Total & 0 & 424 \\
\hline
\end{tabular}

a. Only the monthly reports of 1929 and 1930 differentiate between major-care and minor-care cases. July, 1930, was chosen as a representative month.

b. Monthly reports throughout this period, January, 1929, through December, 1930, indicate that Home Service was active on minor care cases only, with no major-care cases. 
c. As prepared by the Research Committee which prepared the Monthly Report form, major-care cases are "those in which the agency, after investigation, makes a special diagnosis and institutes a plan of treatment." Minor-care cases are those which "the agency does not accept complete responsibility for social diagnosis and social treatment."

d. Of these cases, only seven received relief, to the amount of $\$ 21.77$.

Table III indicates that (1) the preponderance of activity during these years was directed towards claims and benefits for servicemen, ex-servicemen, and their dependents, and (2) only a small part of Home Service activities during this period was directed toward case work.

On June 7, 1938, the Chapter House at 1355 South Third Street was donated to Louisville Chapter by Mr. and Mrs. Charles W. Allen, and permanent headquarters were established. The following year saw many developments. In addition to the regular program, Home Service was finally able to accept for case work service, the guardianship type of case, that formerly after the claim was settled had been left to drift without supervision or guidance.

An example of such a situation was the case of Mrs. X., 68 years old, mother of a disabled World War I veteran. She was receiving $\$ 55.00$ per month, an apportionment of her son's ex-service compensation. Her son was serving a prison sentence for peddling. narcotics and would be incarcerated for several years. Her incame should have been adequate for her needs, but because she spent it unwisely on liquor for herself and friends, it was gone after the first week. Mrs. X. was judged incompetent, and placed under guardianship. The guardian requested American Red Cross to take care of Mrs. X's affairs and arrangements were made for her to live in a boarding home, where she had comfortable lodgings, good nutritious food, and the companbip of other women her age. 1

1. Tbid, 
In reviewing the development of Home Service activities through the peace-time years of the $20^{\prime} \mathrm{s}$ and the $30^{\prime} \mathrm{s}$, it is to be noted; (1) the extended need for service following a war, (2) the preponderance of activity was directed towards preparation of claims, (3) the need for Home Service to serve the peace-time Army and Navy, although the volume of such service is small, (4) the Home Service Section was only incidentally a case-working agency.

There is a noticeable lack of recording of its activitios during these years. Statistics are scant, and there was little attempt to interpret them or account for changes in emphasis. The Home Service Committee minutes for these years are sketchy, and there are gaps of several years between recorded meetings. Annual Home Service reports were made to the Executive Committee, but were not incorporated in detail into their minutes. There is no indication that any attempt was made towards self-analysis by the agency, nor any evaluation of its services. 
CHAPTER II

LOUISVILLE HOME SERVICE, 1940 THROUGH APRIL, 1944. 
LOUISVILIE HOME SERVICE, 1940 THROUGH APRIL, 1944.

\begin{abstract}
September 9, 1939: President Roosevelt announces the existence of a "limited emergency."

August, 1940: The National Guard and other reserves are called to the colors.
October 16, 1940: The Selective Training and Service act goes into offect.

June 30, 1940 to September 9, 1941: The military and naval strength of the United States increases fram 424,280 to $1,964,988$ men.

December 8, 1941: The President approves the joint resolution of Congress declaring that a state of war exists between the United States and Japan.

December 11, 1941: The President approves the joint resolution of Congress declaring that a state of war exists between the United States and Germany, and between the United States and.Italy. 1
\end{abstract}

Accompanying these world-shattering events arose the need for, and the development of, a Red Cross Home Service Department adequate to meet the needs of a nation at war. The Louisvillo Home Service Division stated:

When the President, on September 16, 1940, signed the Selective Service Bill and provided for the Armed Forces to be increased to one and one-half million men, all $\mathrm{H}_{\mathrm{o}}$ me Service Departments became eware of the need to plan and prepare for an increase in work for Military and Naval Welfare Service. The Lovisville Home Service Committee therefore moved to assume the obligation of acting in matters of Voluntary relief in accordance with Military and Naval authorities as a medium of communication between the people of the United

1. "Service to the Armed Forces," prepared by the American National Red Cross, Washington, D.C., Page l. 
States and the Army and Nary.

The Home Service Comittee was imediately enlarged because the Committee believed that to assist in handing the need for increased service there should be an increase of lay participation. The first effects of the program for National Defense were observed by Home Service in November, 1940, when statistics indicated that in addition to the arerage nine active service cases handled, there were three referrals made by Field Directors for direct service to families of active service men, two cases needing service because of the transfer of troops from one camp to another, and a number of intake applications of National Guardsmen recently inducted.

The increase in rvice was first directed towards the Reservists as they were the earliest group to be called in. A number of these men found that they could not care for their families on army pay, and asked for discharges. The home conditions were investigated by Home Service case workers, and reports returned to the Field Directors, who gave such reports to the military authorities for appropriate action. The earlier services were largely based on these requests for Dependency Discharges. When such service to the Reservists had been somewhat exhousted, there was a sudden influx of similar requests from Selectees. Again, investigators obtained a picture of the

1. Home Service Report, Louisville Chapter, American Red Cross, 1940. 2. Ibid. 
home situation for the military authorities and submitted these to them.

\section{Table IV}

Services to Men in the Armed Forces, Louisville Home Service Department, March, 1940, and March, 1941.

\begin{tabular}{l|l|l}
\hline & March & $\mathrm{M}_{2}$ rch \\
& 1940 & 1941 \\
\hline Referrals by Field Directors & 5 & \\
Personal Applications & 16 & 22 \\
\hline Total & 21 & 19 \\
\hline
\end{tabular}

* Of the 22 referrals by Field Directors in March, 1941, 11 were from different military camps or naval bases, 18 were sent as emergencies by telegram, long distance calls, and special delivery air mail letters.

Table IV indicates the 95 (plus) per-cent increase of services to men in the armed forces as the immediate result of the passage of the Selective Service Act, and the preparation for war. Obviously, expansion of the Home Service Program had bogun.

Table V

Intake of Louisville Home Service Department, January, April, and October, 1941, and January, 1942.

\begin{tabular}{l|c|c|c|c}
\hline & $\begin{array}{c}\text { January } \\
1941\end{array}$ & $\begin{array}{l}\text { April } \\
1941\end{array}$ & $\begin{array}{c}\text { October } \\
1941\end{array}$ & $\begin{array}{c}\text { January } \\
1942\end{array}$ \\
\hline $\begin{array}{l}\text { Intake } \\
\text { Case8 }\end{array}$ & 36 & 50 & 142 & 270 \\
\hline
\end{tabular}

Table $\mathrm{V}$ indicates the increase in total intake cases during the period examined, and further indicates enlargement of the program. 
Table VI

Relief and Loans Given by Louisville Home Service

Department, January, Apri1, October, 1941, and January, 1942.

\begin{tabular}{l|c|c|c|c}
\hline & $\begin{array}{c}\text { January } \\
1941\end{array}$ & $\begin{array}{c}\text { April } \\
1941\end{array}$ & $\begin{array}{c}\text { October } \\
1941\end{array}$ & $\begin{array}{c}\text { January } \\
1942\end{array}$ \\
\hline $\begin{array}{l}\text { Amount of } \\
\text { Relief }\end{array}$ & $\$ 33.30$ & $\$ 55.57$ & $\$ 170.83$ & $\$ 256.00$ \\
$\begin{array}{l}\text { Amount of } \\
\text { Loans }\end{array}$ & 44.00 & 75.75 & 160.51 & 140.00 \\
\hline Total & $\$ 77.30$ & $\$ 131.32$ & $\$ 331.34$ & $\$ 396.00$ \\
\hline
\end{tabular}

Table VI illustrates the increase in amounts of relief issued and loans made, and is in keeping with the increase in aases. However, there is another reason which may be cited as accounting for much of the increase in amounts of assistance; to wit, that with the induction of men into service there was a sudden sharp increase in marriages. Figures from the Louisville and Jefferson County License Bureau indicate that in 1939 there were 4,141 marriages; in 1941, 4,664. By January, 1942, many of these "newly married" wives of service men had been forced to give up employment because of pregnanoy, and army pay was not sufficient to meet their living expenses. These wives looked to American Red Cross for financial assistance, and figures of loans and relief grants continued to grow larger. In June, $1942, \$ 604.86$ was issued as relief grants, and \$353.16 in the form of loons.

The problem of providing for dependents of servicemen was not a local one, but national in scope. On June 23, 1942, the President signed the Servicemen's Dependents Allowance Act 
of 1942, which provided for allowances for the wives and children, and certain dependent relatives, of men in the lower grades of the Army; as, enlisted men in the grades of private, private first class, technician fifth grade, corporal, technicion fourth grade, and sergeant. The law provided that, upon the approval of the soldier's application, the allowance would begin. to accrue on the first of the succeeding month following the date of application, and would be payable to the relative or dependents following the end of that montho The allowance would continue to be payable each month thereafter as long as the soldier and his relatives remained eligible for it, up until six months after the end of the present war.

In determining eligibility for allowances, the terms, Class A and Class B were used. Those persons listed under Class A included a lawful wife; a child, (a) a legitimate child, (b) a child legally adopted, (o) a stepchild, if a member of the man's household, including a stepchild who continued as a member of the man's household after the death of the mother or termination of the marriage, (d) an illegitimate child, but only if the man had been judicially ordered or decreed to be the putative father of such child; or had acknowledged under oath in writing that he was the father of such child; former wife divorced who had not remarried and to whom alimony had been decreed and was still payable.

Those persons listed under Class B included: a parent, (a) father and mother, (b) grandfather and grandmother, (c) stepfather and stepmother, (d) father and mother through adoption, 
either of the soldier or his wife, (e) persons who, for a period of not less than one year prior to the man's enlistment or induction, stood in 1000 parentis to the soldier; a brother and sister, including brothers and sisters of the half blood, as well as those of the whole blood, stepbrothers and stepsisters, and brothers and sisters through adoption; grandchild, referring to a child as above defined and limited to persons to whom the soldier has stood in loco parentis for a period of not less than one year prior to his enlistment or induction. The terms, "child," grendchild," "brother," and "sister" were specifically limited to ummarried persons either (1) under eighteen years of age, or (2) of any age, if incapable of self-support by reason of mental or 1

physical defect. Similar provisions were made for dependents of men in the Navy, Marine Corps, and Coast Guard, of the seventh, sixth, fifth, and fourth grades.

In view of the greatly incressed demands and obligations imposed or Home Service with the growing numbers attached to the Armed Forces, the Executive Secretary of the Louisville Chapter invited Miss Ruth Haugen, Special Home Service Field Representative of the National Headquarters, to come and make a study of Home Service organization and activities. In August, 1942, she visited the Louisville Chapter, and made a study of its organization, mechanics of record keeping, making of case records, and so on. Her study revealed that there were several principal phases of

1. "Monthly Allowances For the Dependents of Soldiers" (Washington, D.C., Allowance and Allotment Branch, A.G.O., U.S. Government Printing Office) 1942 . 
Home Service work leading up to the present emergency。

The first phase was: assistance in communication between serviceman and their families, and inquiries in regard to their welfare; giving information concerning regulations and legislation affecting servicemen an their dependents, including assistance in presenting claims for compensation and other government benefits. The second phase named was that of reporting service; cooperation with military and naval authorities by obtaining social history material required for medical treatment, and by making reports on home conditions needed by commanding officers in deciding quéstions of discharge, furlough, or clemency. And, finally, the present stage, that of Family Service involving financial aid for special needs not provided from public funds and basic maintenance, when public relief was not available; consultation and helpful activity directed towards meeting those family difficulties not requiring financial aid, and referral service enabling the client to make use of resources of other organizations providing services not within the Home Service program. Miss Haugan noted that Phases 1 and 2 continued within this present program, also. She stated that this third phase, with which the program was presently confronted, "in the fuller participation of our men in active service, and the resultant needs on the part of many of their families, demand that American Red Cross review its Chapter facilities immediately, to discover if they are adequate to meet the situation." This report, she continued, 
"refers to personnel, performances, and budget."

The findings of the study were incorporated into a report by the Executive Secretary and presented to the Home Service Committee. This report stated that due to the large and rapid increase in numbers of those coming for advice and assistance that records were inadequately kept, and that the agency was rendering an inadequate service, over-looking client problems which should have received attention. In alleviation of these inadequacies, it was suggested that more attention and time be given during the first contact with the client, so that real problems, sometimes not apparent in a hasty interview, might be discovered and assistance given towards solving these problems. It was further suggested that a record be kept of the ways in which requests for service are received by the chapter; as, telegrams, mail from camps and other chapters, personal application, and so on.

Further findings of the study were, that in an emergency, needs are different. It was emphasized that the Chapter must face the necessity of an increasingly large staff of workers, who must have adequate supervision by a person who has had broad experience and the necessary educational background; who has the qualities of good leadership, organizational ability, and the faculty for training those under her supervision. The recommendations were (1) the employment of this "over-all" Supervisor (2) addition of 
two workers to the staff, and (3) addition of one stenographer.

At its meeting on September 12, 1942, the Home Service Comnittee immediately acted on the report. It was recommended that efforts be made to obtain a supervisor, several case workers and discussion was begun regarding increase in salaries in order to retain case workers already in the agency. The Executive Comittee at its meeting on September 14, 1942, sympathetically received the report on Home Service regarding expansion of program, and unanimously approved its adoption. Salary increases were obtained for case workers, bringing the level of pay up to that of Loui sville social agencies; several case workers were employed bringing the total of case workers to eight in November, 1942, as compared with five in November, 1941, and in August, 1943, it was announced that the Department had a full staff as authorized by the Executive Comittee, excepting for employment of a case 2 supervisor.

Table VII

Intake of Home Service Department, January through December, 1942 .

\begin{tabular}{|c|c|c|c|}
\hline MONTH & INTAKE CASES & MONTH & INTAKE CASES \\
\hline $\begin{array}{l}\text { January } \\
\text { February } \\
\text { March } \\
\text { April } \\
\text { May } \\
\text { June }\end{array}$ & $\begin{array}{l}270 \\
248 \\
250 \\
313 \\
384 \\
413\end{array}$ & $\begin{array}{l}\text { July } \\
\text { August } \\
\text { September } \\
\text { October } \\
\text { November } \\
\text { December }\end{array}$ & $\begin{array}{l}464 \\
524 \\
467 \\
585 \\
653 \\
808\end{array}$ \\
\hline 1. & & & \\
\hline
\end{tabular}


As indicated by Table VII, each month in 1942 evidenced a steady rise in intake. By August, the Home Service Comittee had begun to recognize the need of larger quarters for Home Service. They were then housed in the chapter house. Because of crowded quarters, there wes little opportunity for privacy of interviewing, insufficient room for records, and inadequate waiting room fecilities. Added to these conditions was the recognition that there would continue to be a steady increase of applications. A sub-committeo was chosen to obtain now quarters, and by February 1, 1943, Home Service Division offices were moved to its present location 307 South Fifth Street. These quarters provided for a large, comfortable waiting room, individual interviewing booths for intake workers, a record room, telegraph room, telephone room, and pritate offices for the Intake Supervisor and Staff Service Supervisor. In addition, small offices are provided for the district case workers, two to each office, allowing for scheduled office hours so that client and worker may speak together in privacy. Also, provided are private offices for the district supervisor, and the director, plus a staff-meeting room, typists' office, and dictation room. Quarters are not spacious, but adequate.

The Home Service Committee seems to have been, throughout this expansion period, an actively funotioning, alert group of "lay" members of the community, aware of its responsibility and eager to give maximum performance. In December, 1942, it saw the

1. Minutes, August 25, 1942 . 
need to review its position, and drew up the following

statement:

The Home Service Committee is made up of members selected because of their interest, understanding and leadership.

Its purpose is to serve as a planning, policyevaluating, advisory and organizing group.

Its functions are: (1) to be informed on American Red Cross activities and procedures affecting the welfare of men in service in the Armed Foraes; and disabled ex-servicemen and their families, (2) to be informed on local welfare problems and the service of the agencies in the community to meet local needs, (3) to re-eraluate National policies in terms of local situation, to assist in formulating policies for effective work with other agencies, and define lines of responsibility in relation to other commuity welfare agencies, (4) to formulate practices and procedures applicable to the local Chapter for carrying out the Chapter obligations as set forth in National policies, (5) to assure itself that adequate funds are available so that no family of a serviceman or exserviceman suffers hardship as a result of the man's service in the Armed Forces, (6) to determine needs as they arise for paid staff and volunteer assistants, and to pass on suitable qualifications of such workers, consistant with National policies. (7) to recommend an adequate budget not only for administrative costs, but for Home Service relief: to assist the Chapter Board in properly evaluating the service in terms of benefit to the community and to assist the budget committee in the financial needs of the service in preparing the annual budget, (8) to review and give advice on all problems pertaining to the effective administration of the Home Service program, (9) to serve as a medium of interpretation of Home Service to the Executive Comnittee and to the community, and, (10) to take Home Service action and recommendations to the Exeoutive Committee. (Actions of the Home Service Committee are subject to the approval of the Executive Cormittes). 1

Also discussed at this time by the Home Service Committee was a staff development program. They recommended (1) regular staff meetings, (2) regular scheduled supervisory conferences, 
(3) staff evaluation, (4) in-service training, (5) educational leave, (6) encouragement of the staff in using University froilities.

As previously indicated, any new or changed government regulation or order has been immediately felt in American Red Cross case loads. The average number of cases interviewed during the weok of February 8, 1943, was 76 (plus) daily compared with 49 (plus) for the same period in Jenuary. This was partially explainable by the change in location, making the offices more accessible, but another factor was an item of procedure of the Office of Dependency Benefits, in which a notice was sent to all recipients of allotments and allowances in connection with the establishment of their eligibility. A large number of requests of advice and service followed.

The agency had also begun to receive referrals for the investigation of Class $B$, or dependency, allotments. It was recognized that within several months this would develop into many increased applications.

There was an indication, from January, 1943, figures, that the amount of relief and loans might not continue to increase in proportion to the general case load increase. These figures were $\$ 3,739.06$ in January, as compared with $\$ 5,831.00$ in December, 1942. This indicated that the payments of dependency benefits were becoming more stabilized and regular and relief needs would not be so serious as they had been. The increased re-payment of loans was an indication of this same trend - that is $\$ 1,853.00$ 
was repaid in January, as compared with $\$ 794.00$ in December.

At its meeting in November, 1942, the Home Service

Committee discussed the need for night and Sunday services. At

this time there was no after-hour service, and there had been

roiced a number of complaints regarding this inadequacy. A

committee member was authorized to look into the matter to see if any students at the University would be interested. In January a medical student was secured for night work. He was trained to handle the simple kind of emergencies, and instructed to telephono a member of the regular social service staff to aroid making decisions too complicated for him. By February, Home Service was covered daily - excepting Sunday, from 8:30 a.m. to 10:00 p.m. To assist the night worker there was organized a volunteer group of twenty social workers, who were members of the staff of other agencies. They were given a brief course in orientation, and each was assigned to one night per week. They gave valuable assistance in communication and reporting service. Plans were also in progress for Sunday coverage, but were held in abeyance as the office building was not heated on Sundays. Reporting service was made available on Sundays, however, with staff members receiving and acting on telegrams and other messages from their homes. On May 11, 1943, the Emergenoy Maternity and Infant Care Program became effective in the state of Kentucky. This program operated under federal funds appropriated by Congress, provided for prematal cáre, hospital and medical facilities for delivery, 
and medical and/or hospital care for the infent for one year following birth. These henefits were to be available to the wires and children of men in the Army, Navy, Coast Guard, and Marines, of the four lowest pay grades. The program was to be administered by the State Board of Health, which was given the power to authorize care.

\section{Table VIII}

Cases in Kentucky Authorized for Care Under the Emergency Maternity and Infant Care Program, May through September. 1943.

\begin{tabular}{l|c|c|c|c|c}
\hline & May & June & July & August & September \\
\hline No. of Cases & 400 & 492 & 584 & 604 & $700 *$ \\
\hline
\end{tabular}

* Stat ement by Dr. Chenoweth's Office, State Board of Health, Personal Interview.

As indicated by Table VIII, the program went into immediate effect, and large numbers of cases were accepted. This program had an early effect on Red Cross expenditures for medical and hospital care. In July, 1943, expenditures for these needs accounted for only $\$ 696.53$ of the total expenditures, as compared with $\$ 959.54$ in June, and $\$ 1,798.88$ in May- a reduction in costs for medical and hospital care of $27.4 \%$ over June and $56.6 \%$ over May. At this time, the largest requests made for service were in connection with securing government benefits to which dependents of servicemen or ex-servicemen were entitled, and for investigations relating to emergency furloughs and furlough extensions because of an emergency 
existing in the homes of active servicemen. Statistics for

the month of July reveal that of the cases acted on, 383 were requests for information, 377 were furlough investigations, 74 were assistance with government claims, and 119 assistance with 1 government benefits.

By September, 1943, there was a decided increase in the number of referrals of active service men being discharged from the army and havy hospitals because of disabilities. Of these, $50 \%$ of the disabilities indicated mental and emotional disturbances, although few had, as yet, served in overseas duty. This indicated a problem that the community would be facing with increased seriousness as the war progressed. The inorease in returning disabled veterans caused a proportionate increase in Home Service claims service. Statistics indicate that ther were 86 persons assisted with government claims in September, a.s compared with 57 in August. September also brought attention to the problem of supplementation of government "femily allowances." In many cases, particularly those in which persons had been accustomed to a high standard of living, they found that they could not manage for themselves and children, on the amount received from the allowance, and applied to Home Service for additional help. In considering the problem, Red Cross reached the decision that it is essentially an emergency agency, and financial assistance can be given only to meet emergency needs; that, whereas supplementation might be given 1. Home Service Report, Louisville Chapter, American Red Cross, July, 1943. 
to meet special needs, it may not be given regula rly as basic maintenance. Opinion of the Home Service Committee seemed to indicate that it was the responsibility of the government to provide adequate basic maintenance。

In recognition of this responsibility, Congress passed new legislation in October which greatly increased the amount of allowance for dependents of active service men, and increased the service grades eligible for the allowanees. It was believed that this legislation would effect more prompt and adequate allowances for dependents and should prevent many emergency needs. Because of the gigantic task required for the Office of Dependency Benefits to make these changes, most of them did not appear until January or February, or even March, 1944. Meamwhile, November, 1943, brought a large increase in cases due to requests for service in filling out the new government forms which dependents had been sent in connection with changes in the allotment law. Financial assistance also increased, from $\$ 642.69$ in October, to $4,760.72$ in November, expended on $10 \%$ additional cases. The greater part of these expenditures were for living expenses for dependents of active service1

men while their allotments were pending. The increased amounts of assistance was due to the induction of fathers, leaving dependent families to be cared for.

In November the auditor's check revealed a need for more specific policies on loans and grants, as there were unpaid loans which had extended over a period of months. This subject had been

1. Ibid. November, 1943. 
under discussion from time to time. At its meeting on June 15. 1943, the Home Service Committee had advised that relief grants should be given when the worker had gone into the financial resources of the family and found them unable to meet the needs for which they were requesting assistance, nor could they expect to have resources to repay any advance made by Red Cross. On the other hand, if family resources would be such that they could repay advances within a reasonable length of time, then 2 assistance was to be given in form of a loan.

At the auditor's recommendation, the Home Service Committee at its meeting on November 16, 1943, reviewed its policies regarding loans and grants. It was agreed that loans were to be made only when the applicant's potential income showed that a loan could be repaid without hardship. It was stipulated that Red Cross would not consider as resource to the client his insurance, tangible personal property, or war bonds. The Committee passed a motion regarding the following statement of policy:

Assistance from chapter funds should be given as grants to those persons for whom benefit payment may be expected in amounts barely sufficient to meet their future continuing needs. If the payment is expected to be sufficient to meet current expenses, as well as repay the chapter for assistance in the pending period, chapter aid may be given with the understanding that it be repaid. 3

1. Ibid. November, 1943.

2. Minutes, June 15, 1943.

3. Ibid. November 16, 1943. 
These recommendations were discussed with the staff, and it was emphasized that a decision should be reached on a case-work basis, after careful budgeting with the family.

The volume of night and weak-end calls for service was increasing. In October there arose the question of a possible need for 24-hour service. Letters were written to cities of similar size to learn how they were handling these calls, and it was decided to keep account of all telegrams. local and longdistance telephone calls after hours from November 1 to January 1. Meanwhile, there was a large inorease in night and week-end telephone calls and emergency telegrams, which made necessary the addition of one full-time emergency worker and two part-time night and week-end workers. In January the two months' record of after-hours needs was studied, and it was found to indicate a not too serious need for extension of hours. It was decided, however, to continue to keep a record of emergency telegrams and telephone calls. In February this decision that there was no need for 24-hour service was reversed, and a search was begun for personnel to extend service to a 24-hour coverage. To date, however, securing of this personnel has not been achieved.

February brought a tremendous increase of pressure on the department due to the passage, on February 2, 1944, and effective immediately, of the Mustering-Out Pay Bill. This bill, passed by Congress, guaranteed veterans of World War II cash payments to help them make an adjustment from military to civil life. Payments were: $\$ 100.00$ for less than 60 days service in the United States; $\$ 200.00$ 
for over sixty days service in this country, and $\$ 300.00$ for service overseas or in Alaska. For these three groupings, $\$ 100.00$ was to be paid immediately, the rest in monthly installments. During the month of Febmary, 1,800 requests were made for service in filing applications for Mustering-Out-Pay - Many of the disabled ex-servicemen who applied for these benefits also asked for assistance in filing claims for compensation, for which they had previously neglected to apply. There were a total of 3,885 persons in the office in February, as compared with 1,677 persons in January. This sudden tremendous surge of persons requesting service presented an almost staggering task. It is to be noted, however, that no one was turned away, and that the staff met the needs for service of all applicants, with a minimum of delay. Of the $\$ 4,605.53$ issued as financial assistance during the month, only $\$ 719.62$ went to ex-service-men and their dependents; an indication that for the most part even the disabled service man was having little trouble in finding work, and was not requiring financial assistance pending adjudication of his claim.

February also brought forth a formal agreement with Army Emergency Relief, in which, and contrary to previous practices, there was set forth certain instances in which American Red Cross might refer cases to the former agency.

In March, 1944, the Home Service Committee recommended availability to the staff of Tuition Scholarships at the University. Also, in March, a spot check was made of active cases, in which it was learned that $22.5 \%$ of these were non-residents. The ramifications 
of this will be discussed elsewhere; as will the entire problem of medical care for dependents of servicemen, and particularly for non-residents. Let it suffice at this time to state that in April, Home Service reviewed its present medical policy. This policy stated that:

All legal residents were to be referred to the General Hospital, non-residents were also to be referred to the General Hospital, excepting only in unusual circumstances where emergency hospitalization has been necessary, and there had been no time for the physician to see if the patient was able to pay for a private hospital; or if for same unusual reason the physician needed to continue his care of the patient and thus could do so only in a private hospital. 1

The use of volunteers in the Home Service program was an out-growth of the expansion period. In February, 1940, the first course in Staff Assistance was inaugurated. Forty-ono women completed the course consisting of twenty hours of lectures relating to the origin and history of the Red Cross and describing all its services. Of the Staff Assistance Corps, the Chapter Manual states: "aiding in office work; in assisting other service or carrying out any special duties proposed by their chairman and approved by the Chairman of Volunteer Service.

- This service could be composed of women who have taken the Staff Assistance course of lectures, and who may be trained for future leaders of Volunteer Service." The Staff Assistance Corps expanded in proportion to enlargement of Red Cross program. In 1941, 42

\footnotetext{
1. Minutes, April 15, 1944.

2. "Chapter Manual," The American National Red Cross, Washington, D.C., July, 1940.
} 
volunteers gave 420 hours; from January through May, 1943, 425 volunteers gave 13,560 hours. These figures include the Staff Assistance Corps placements in all divisions of the Louisville Chapter; as, Blood Donor, Chapter House, Home Service, etc. Since 1941, members of this Corps have filled assignments in the Home Service Department as receptionists, file clerks, typists, and other clerical jobs. To quote a few recent figures on use of the volunteers: In February, 1944, when there was the tremendous rush of persons into the office because of the passage of the Hustering-Out-Pay bill, the agency enilisted the aid of as many volunteers as were available. It is to their credit that they responded to the increased need and did an excellent job of helping. During the month, a total of 77 volunteers gave a total of $1,214 \frac{1}{2}$ hours of service, which was $2 \frac{1}{2}$ times the volunteer, hours given in January. In March, 1944, 32 staff assistants gave 634

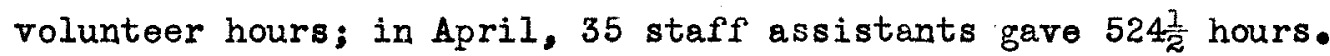
This is in addition to the hours given by rolunteers who are not members of the Staff Assistants Corps, not having completed the course. In April, 1944, 48 such volunteers gave $690 \frac{1}{2}$ hours. The use of volunteer social workers assisting with night and Sunday duties, as previously mentioned, was discontinued in December, 1943. From time to time there has been mentioned the possibility of organizing a Volunteer Home Service Corps, to assiat the caseworking staff. On September 15, 1942, the chairman of the Home Service Committee announced that he had received a letter from Mrs. F.L. Almstedt, Chairmen of Voluateer Special Service, offering 
her cooperation in forming a Volunteer Home Service Corps. She was told at that time to begin recruiting desirable personnel for such a corps, but that the corps could not be organized until a staff increase would permit of sufficient 1 supervision. To date, there has been no organization of such 2

a Corps.

It is interesting to note that the concept of use of volunteers in Home Service did not originate with World War II. In 1918, "The Community" stated:

A war-time activity of the Associated Charities has been the training of volunteers for American Red Cross Home Service. These courses tend to give a real insight into the meaning and purposes of family rehabilitation and to give a brief outline of the processes. Active field work is given in connection with the Associated Charities, Juvenile Court; and Federation of Jewish Charities. Required reading is a feature of the course. Eighty women are receiving this training. 3

1. Minutes, September 15, 1942。

2. Since compilation of this paper, organization of a Home Service Corps has begun.

3. "The Community," (May, 1918), page 15. 
CHAPTER III

COMUUNITY COOPERATION 
CHAPTER III

COMMUNITY COOPERATION

Sub-Committee on Intake - Council of Social Agencies

To complete the picture of Home Service, it is necessary to include the interaction of the agency with other cormunity social agencies in order to gain a complete view of its activities and place in the community.

In Norember, 1929, the Council of Social Agencies organized the Inter-Agency Committee. Based on the activities of this committee, the Council has prepared yearly reports on inter-agencies action, and has formulated statements of division of responsibility.

In 1939 , the Council of Social Agencies reorganized its Inter-Agency Committee, and it became the Intake Committee of the Family Welfare Division.

The concept of conmunity cooperation is not a new concept to Home Seevice. As early as 1920 there is a record of a number of meetings arranged by Red Cross and attended by 211 clubs, organizations, and agencies in any way dealing with ex-servicemen to inform the public of all possible services to ex-servicemen, and to eliminate duplication. Again, in July, 1924. Red Cross arranged for a discussion with the American Legion to determine the best way in which World War Bonus claims could be taken care of by the two Organizations without duplication of effort, and it was at this time that the decision 
was reached to place a Red Cross worker at Legion headquarters to assist in the filing of World War Claims forms.

The minutes of the Inter-Agency Committee indicate participation by Red Cross whenever community problems fell within its sphere.

August, 1943, saw the beginning of what promised to be a strong community organization directed primarily towards the solution of problems of the families of men in the armed services, towards the veterans, and their families. When Miss Margaret Woll began her duties as director of Home Service in June, 1943, she irmediately became concerned over the number of cases coming to Red Cross involving referral to other agencies. It had been accepted that it was not possible for Red Cross to handle all cases of sevvice men's families, and there appeared the need for discussion regarding division of responsibility. Through the efforts of Miss Woll, and with the cooperation of the Council of Social Agencies, on August 18, 1943, a meeting of the SubConmittee on Intake was called, with representatives of Red Cross, Family Service Organization, Municipal Bureau of Social Service, Traveler's Aid, Children's Agency, and the Council of Social Agencies attending. The statement of purpose of this meeting was to discuss the division of responsibility for families of men in the armed forces, and for responsibility to discharged servicemen. Decisions reached at this meeting were:

(1) Red Cross will assume responsibility for veterans and their families during the period of investigation of their claims by Veteran's 
Administration. This is in accord with National Red Cross policy.

(2) Municipal Bureau of Social Service will accept cases of resident Veterans whose claims have been adjudicated.

(3) Families of service men whose allotment have been discontinued because the man has been placed in the Rehabilitation Center, may be referred to the Municipal Bureau of Social Service.

(4) Family Service Organization would accept a few referrals from American Red Cross where supplementation and case work service were desired, but could not consider this a regular policy. 1

Other situations discussed, but on which no decision

was reached, were:

(1) The problem of servicemen's children who were receiving an allotment which was insufficient. The opinion of the group leaned towards the responsibility of Aid to Dependent Children, but because this agency was not represented, such opinion could not be verified.

(2) The situation of divorced parents, in which the man was in service, and the allotment for the child or children was insufficient to provide board for the children, the Children's Agency stated that it would not provide this support if there were no hope for family reconciliation. Juvenile court stated it has referred some such cases to Red Cross, but Red Cross affirmed that it did not feel that this was their responsibility. No decision was reached. 2

Before adjourning, the Committee moved to meet once each week, discuss cases and thereby arrive at a closer understanding of division of responsibility. It further determined to enlarge its scope by inviting representatives of other agencies and

1. Minutes of the meeting of the Sub-Conmittee on Intake, Council of Social Agencies, August 18, 1943.

2. Ibid. 
related organizations in the city. In pursuance of such a policy, meetings have been attended by, in addition to those already enumerated, representatives of Mental Hygiene Clinic, Social Service Exchange, Nichols General Hospital, Louisville General Hospital, Jewish Welfare Federation, United Service Organization, Children's Center, Home of the Innocents, and Aid to Dependent Children of the State Welfare Department. In addition, sub-comittees have been utilized to work with community problems, and these committees have met with Dr. Hugh R. Leavell, Louisville and Jefferson County Health Department, and Mr. Hansbrough, War Manpower Commi Bsion.

To evaluate the action of the comitter, its activities and decisions will be examined.

\section{Financial Relief}

In discussing responsibility for financial relief, Red Cross renewed its National policy before the Committee, stating that:

Financial relief can be given from American Red Cross funds to meet special needs not provided from public funds, and basic maintenance when public relief is not available. When clients are eligible for public relief, they may be referred to the public welfare agencies, with Home Service continuing ... financial assistance for other needs. 1

As previously indicated, Red Cross accepted full responsibility for veterans and their families during the period of investigation of their claims. 
The Municipal Bureau of Social Serrice, as stated, agreed to accept cases of veterans whose claims have been adjudicated, and of families whore the serviceman is in the rehabilitation center. The Municipal Bureau of Social Service accepted the responsibility of cases awaiting Aid to Dependent Children, Old Age Assistance, and Aid to the Blind, regardless of their connection with a serviceman, if there was need for financial assistance. ${ }^{1}$ They also agreed to accept all local single discharged servicemen.

Family Service Organization agreed to consider for financial help any cases having need for case work service as well as relief and desiring the services of Family Service Organization. However, they did state that such cases could not be accepted as a general policy.

\section{Case Work Service}

In addition to case work services for all clients receiving financial assistance, Red Cross affirmed its policy of continuing with "non-relief services" to dependents of service men, veterans and their dependents even while such cases might be receiving public relief. Family Service Organization stated that it would accept for case-work services certain veterans needing help with personality problems, and that it would be avilable when requested to consider acceptance of cases of the families of service men and ex-service men 
needing more extensive case-work service than American Red Cross felt able to give. Aid to Dependent Families stated its policy of providing case-work services for all Aid to Dependent Children families whether or not there was a need for supplementary financial assistance.

\section{Army Bmergency Relief Program}

At its meeting on September 9, 1943, the group decided that in order to prevent duplication of relief between the agencies and Arny Emergency Relief, to contact the A.E.R. representatives at Bowman Field, Fort Knox, and Nichols General Hospital, to learn of their programs, and to suggest that a representative from each meet some time with the group. On October 21, 1943, Lt. Blood, Army Emergency Relief officer from Nichols General Hospital, met with the group. He stated that Army Emergency Relief accepted cases:

(1) that were of a confidential nature,

(2) that were emergencies and could not be handled as quickly by American Red Cross or other agency.

(3) which American Red Cross had not handled to the so.tisfaction of the Army Emergency Relief officer.

In discussing the program, It. Blood said that Army Emergency Relief had been estaolished in February, 1942, with the expectation of supplementing the work of American Red Cross in emergencies. Its first money was obtained by a loan of one 
million dollars from American Red Cross. Additional funds have been received from outright gifts and from benefit performances, which now support the organization. In discussing cooperation with American Red Cross, he stated that the immediate needs of the soldier and his family are cared for, and the case is then referred to American Red Cross. It was also pointed out that American Red Cross is frequently requested to make the home investigation, and to give its recommendations regarding a loan. Lt. Blood indicated that the agency has found little occasion of duplication with American Red Cross. However, at the suggestion of the group, he agreed to send in facts to the Social Service Exchange regarding cases in which Army Emergency Relief accepts 7 for assistance.

\section{Problem of Legal Residence}

At its meeting on September 16, 1943, the question of verification of legal residence was approached. Red Cross stated that it had been receiving approximately ten requests per month for such service. It was determined that verification of legal residence is properly the function of Public Welfare, and that all requests are to be referred to the Municipal Bureau of Social Service. In doubtful cases, the Municipal Bureau is to confer with Red Cross before a decision is reached.

1. Ibid, October 21, 1943. It is to be noted that Lt. Blood was transferred from this vicinity soon after this meeting, and A.E.R. policies in relationship to A.R.C. were again changed. 
The problem of Legal Residence which has arisen in Louisville following the growth of Fort Knox, and Bowmen Field as army installations, is of girls who are Louisville residents marrying non-resident service men. The ruling of the Law Department of the City of Louisville states that Louisville wives of non-resident service men lose their residence in Louisville. The Committee discussed planning for those girls who have followed their non-resident husbands to another camp, became stranded and requested to be returned to Louisville. Under the Law Depertment ruling, the Municipal Bureau cannot return these girls; it was determined, however, that they might advise the inquiring agencies when the girls' families are willing and able to accept the girls. This Law Department ruling has also produced the serious problem of medical care for this group of "non-resident Louisville residents." At its meeting on September 23, 1943, the Committeo first approached this question. It was decided that s sub-committee meet with Dr. Leavell to discuss all aspects of the problem, and to attempt to work out a solution and better understanding with the Louisville General Hospital.

On October 14, 1943, the sub-committee reported to the group. It stated that it had reached the following conclusions in its discussion with Dr. Leavell:

(1) Louisville General Hospital will provide emergency exeminations to non-residents at no charge.

(2) Agencies will be charged $\$ 3.50$ per day for hospital care to non-residents. If, however, the patient can pay only part of this fee, such pay will be accepted. 
(3) Louisville girls who have married nonresident soldiers, will not be accepted for free medical treatment.

The Committee was greatly concerned over the ruling in regard to the "technical non-residents" (girls married to nonresident soldiers). In many ways this involved the sudden cessation of medical and clinic care to girls who had been receiving treatment over a period of years. On January 8, 1944, Mrs. Louise Wood, Executive Secretary of the Council of Social Agencies, wrote to Dr. Leavell. She stated:

Following our meeting in the Law Department office, I talked to $\mathrm{Mr}$. Charles Morris as Chei rman of the Mayor's Legislative Comittee about the possibility of legislation which would entitle Louisville girls who became technical non-residents through marriage to non-resident soldiers (and their children) to community resources for the duration of the rar. Mr. Morris suggested I present this question to Niayor Wyatt.

Therefore at a recent conference ... I had the opportunity to mention the question of technical non-residents, and their need for public service, especially medical and hospital care. The Mayor suggested that the Board of the Louisville and Jefferson County Health Department be asked to consider this matter.

American Red Cross reports that payment for hospital and medical care for sixty-two technical non-residents in the first eleven months of 1943 totaled $\$ 3,424.12$. About one-half of this amount was to Louisville General Hospital.

In the event that you would like to have representatives of the Council Committee present this question of free medical and clinic care for technical non-residents to the Board of Health, I shall be.glad to arrange this. 1

1. Letter from Mrs. Louise Wood, Executive Secretary of the Council of Social Agencies, to Dr. Hugh R. Leavell, Director, Louisville and Jeflerson County Health Department, January 8, 1944. 
The Committer contirued to be active in working with this problem, and created considerable community interest in it. On January 23, 1944, an editorial appeared in the Courier-Journal, entitled "What is a Residence Privilege, Anyway?" It stated:

The decision of the City-County Health Board to refuse free service to Louisville women who have married men from other cities seems miserly and unjust. It must be news to Louisville women who have married soldiers from other cities but continue to live here that they have lost 'resident privileges', particularly as they have not gained such privileges anywhere else. Surely any woman who, before her marriage, was eligible for free hospital care remains equally eligible after marriage if she remains here as a resident and is married to a man who temporarily has no residence.

The legal point on whi h exclusiveness is based must surely be rather fine. The United States Government does not consider that a woman who marries a foreigner has lost either her citizenship or her residence rights.

Space at the General Hospital at the moment is not at such a premium as to make this decision one of sheer necessity. And its application as a matter of choice seems likely to make Louisville unenviably notorious for cheese-paring where the wives of soldiers are concerned. 1

In February, nine American Legion Posts sent resolutions to the Fiscal Court of Jefferson County and the Board of Aldermen of the City of Louisville as going on record in requesting that they take steps necessary to remedy the situation of young women residents marrying non-residents, and therefore losing eligibility for free hospitalization and service at the Louisville General Hospital. To date, the decision still stands. However, it is

1. What is a Residence Privilege, Anyway?" The CourierJournal, Louisville, Kentucky, January 23, 1944, page 6. 
resonable to suppose that this community pressure may bring

a reversal of the decision within the near future。

Registration of Cases

On October 14, 1943, a representative of the Social

Service Exchange attended the sub-comittee meeting. As a result of discussion during this meeting, it was decided that American Red Cross should register cases on a selective basis. It was decided that registrations should not be made on cases of emergency furloughs, information cases, or disability referrals until the veteran applies for some type of assistance.

\section{Psychiatric Care For Veterans}

At its final meeting for September, 1943, the Committee began discussion on the problem of the veteran returning to his family with a discharge based on a mental condition. American Red Cross reported that it was receiving an increasing number of these cases, and it was recognized that the community would have to face the problem of these disabled veterans. It was believed that the community should be ready to meet this problem, and that a united agency approach would be helpful.

Dr. Ackerly, Medical Director, of Mental Hygieno Clinic, was invited to attend the following meeting on October $7,1943$. He urged that the veteran be helped immediately after discharge, as the first six months following his discharge is the most difficult period for him, as he must then make the real adjustment 
to civilian life. Dr. Ackerly suggested referral of veterans as follows: psychotic patients to Lakeland Clinic, held at Louisville General Hospital; psychopathic patients to Louisville General Hospital clinic; and those patients with a better history and better outlook for readjustment of emotional difficulties might be referred to Mental Hygiene Clinic. However, the psychiatrist recognized the limitations of facilities for psychiatric care of veterans in Jefferson County. At his suggestion, on October 21, 1943, the Comnitteo sent a letter to Dr. John D. Reichard, Medical Officer in Gharge, U.S. Public Health Service, at Lexington, Kentucky, in regard to the possibility of establishing an out-patient clinic for veterans at the Marine Hospital. The letter stated that American Red Cross had received, in the period from September 1 to September 20, notification of ninety-four discharged, disabled veterans. of this group twenty were discharged because of nervousness, one with schizophrenia, and two with emotional disturbances. It pointed out that the out-Patient Clinic at the Louisville General Hospital is unable to meet the demands because of a reduction in staff. Further, many of these veterans are non-residents of Louisville. Dr. Reichard's reply stated that psychiatric service could not be furnished by the United States Public Heal th Service

1. Minutes of the meeting of the Sub-Comnittee on Intake, Counoil of Social Agencies, October 7, 1943.

2. Letter from the Sub-Committee on Intake, Council of Social Agencies, to Dr. John D. Reichard, Medical officer-in-Charge, U.S. Public Heal th Facility, Lexington, Kentucky, October 21, 1943. 
1

at the Marine Hospital. The Committee therefore suggested that a letter be written to Dr. Miller, Veteran's Administration Hospital in Lexington, asking advice on how to proceed for this need. The Committee further suggested that, upon the approval of Dr. Miller, a letter be written to General Hines, Head of Veteran's Administration in Washington, D.C.

Considerable correspondence has been had with Veteran's Administration regarding this need. Up to September, 1944 an out-patient clinic at Marine Hospital has not been established. It seems likely, however, that with continued activity of the Committee, such froility may be obtained. That there is great need, is indicated by figures issued in February, 1944, stating that Army discharges had numbered 40,000 and that 25,000 of these were psychiatric cases. For Louisville's share of these cases, there is no place nearer than Lexington, Kentucky, for their counseling and care. Job Placement For Veterans

At its meeting on October 21, 1943, a sub-committer, composed of representatives of American Red Cross, Council of Social Agencies, and Muricipal Bureau of Social Service, reported on its meeting with Mr. Hansbrough, War Manpower Commission. It was stated that the War Hanpower Comission had set up a special

1. Letter from Dr. John D. Reichard, Medical Officer-in-Charge, U.S. Public Heal th Froility, Lexington, Kentucky, to Sub-Committes on Intake, Council of Social Agencies, December, 1943.

2. Material used in study does not go beyond September, 1944. (See Introduction). 
office in the United States Employment Service, for veterans, with a placement officer. In addition to the placement officer, the United States Employment Service had begun the service of sending a representative to Nichols General Hospital and Fort Knox, on scheduled days.

The question was raised regarding the possibility of assigning a social worker to duty at the Employment Offico. However, War Manpower Cormission did not find this practical. The Cormittee therefore decided that the United States Employment Service might refer any veteran applying for a job and found to need counseling service or other aid, to a clearing house, which would refer the veteran to the proper agency. The Municipal Burea of Social Service was chosen as the clearing house. In December, 1943, the United States Employment Service reported on its veterans placements for the year. The report follows: January - 179; February - 178; March - 198; April - 399; May - 502; June - 525; July - 595; August - 524; September - 798; October - 772; 1

November -873 .

\section{Where to Refer}

The Sub-Committee on Intake recognized the value of compilation of a precise statement of agency service in Louisville, which would be made arailable to service men, their dependents, ex-service men, and their dependents. Following a meeting of the

1. Minutes of the Meeting of the Sub-Committee on Intake, Council of Social Agencies, December 9, 1943. 
Committee in January, a sub-committee met to discuss organiration of such a pamphlet. A form was distributed asking for (1) name of agency, (2) location, (3) person in charge, (4) coverage, (5) eligibility requirements for assistance given, (6) legal residence requirements, (7) kind of assistance given, (8) other service offered besides financial assistance, (9) ability to meet requests for service needing immediate action, (10) hours in which application may be made. The agencies filling out this questionnáire were: Juvenile Court, Army Emergency Relief, Nichols General Hospital, United States Bmployment Service, Visiting Nurse Association, Municipal Bureau of Social Service, Lovisville and Jefferson County Health Department, Louisville General Hospital, Medical Social Service Department, Louisville General Hospital, Jewish Welfare Federation, American Red Cross Home Service, Jefferson County Welfare Department, Femily Service Organization, Children's Agency, Army Emergency Relief, Bowman Field and Salvation Army. These questionnaires were compiled, and in April, 1944, a pemphlet entitled "Do You Know Where to Refer Servicemen and Servicewomen and Their Dependents in Jefferson County, Kentucky?" was made available. One hundred and forty-three copies were distributed to members of the Intake Committee for their staff members.

The Returning Veteran

Planning for the returning veteran is being done by social agency groups throughout the country. It is interesting to note part of the program of the Midwest Chest Council Conference, 
in February, 1944; discussions were held on the following

topics (1) Does every community need a central committee on returning servicemen? Who is to be represented? (2) What is the place of veterans organizations in the local central planning committee? (3) Should one or more information centers be set up to refer returning servicemen to appropriate community service? (4) What is the place in this program of veterans claims services under private auspices? (5) Should the central committee interest itself in veterans legislation? To what extent, and in what 1 nature?

It is to the credit of Home Service that, under Miss Woll's direction, it has taken an active part, an in many matters the leadership, in working with the Council of Social Agencies: Sub-Committee on Intake, thereby making easier the lot of many servicemen, ex-servicemen, and their families.

1. Programs in the discussion, "Planning for the Returning War Veteran," Midwest Chest Council Conference, Chicago, Illinois, February 25, 1944. 
CHAPTER IV

ORGANIZATION AND SERVICES

OF

LOUISVILLE HOME SERVICE DE'PARIMENT 
CHAPPER IV

ORGANIZATION AND SERVICES

OF

LOUISVILIE HOME SERVICE DEPARTMENT

Local Home Service divisions function within

the limits of national policy as determined by the National

Red Cross. The governing body of the national organization

is the Central Comittee, consisting of eighteen members:

six appointed by the Board of Incorporators, a self-perpetua-

ting body of sixty-five persons; six appointed by the President

of the United States; and six appointed by the Chapters. It

is this Central Committee which is responsible for initiating

all Red Cross activities, and of formulating Red Cross policies. 
ORGANIZATION OF AMERICAN NATIONAL RED CROSS

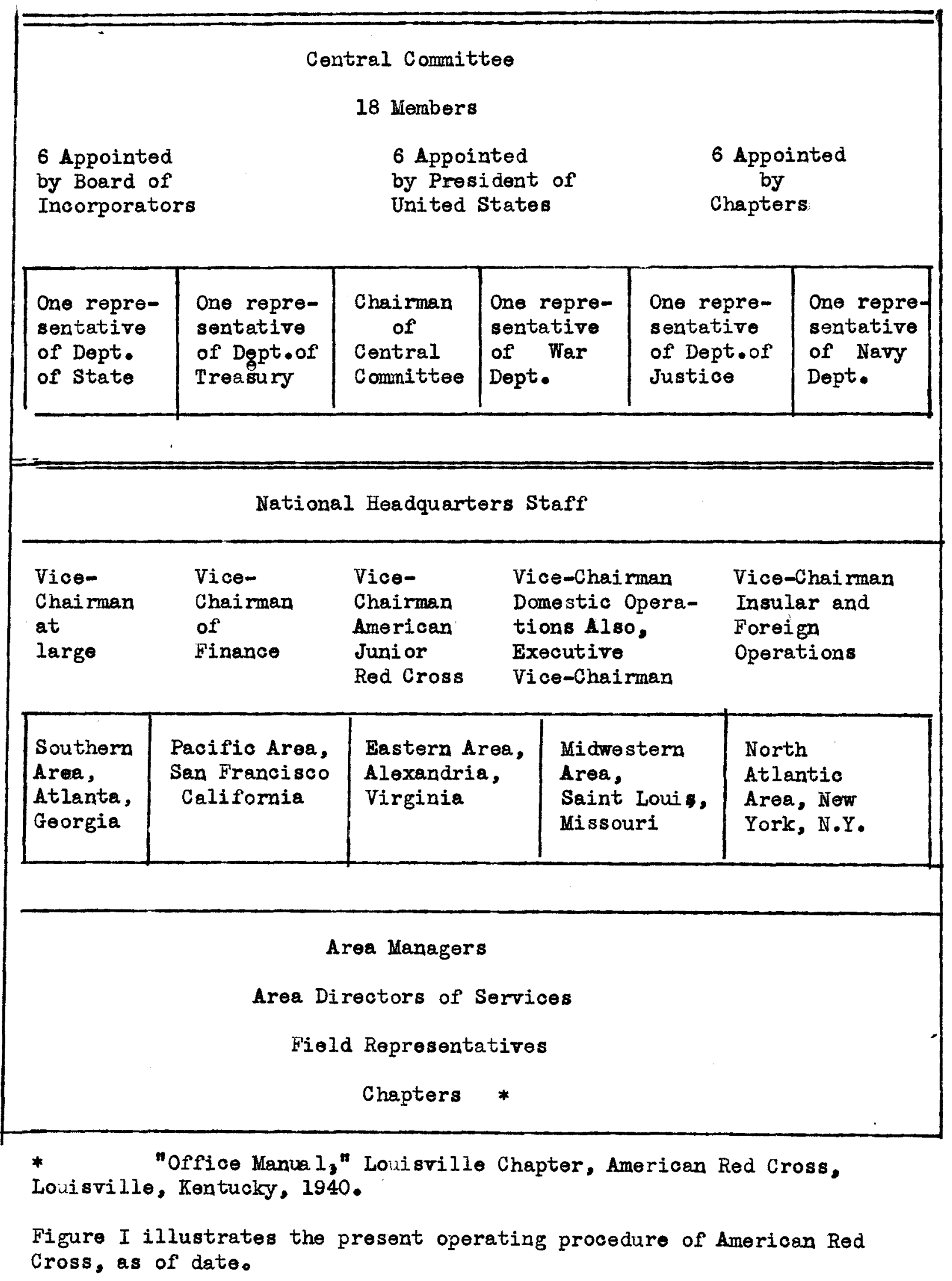


Although local Home Service divisions function within the confines of national policy, there are local interpretations, policies and decisions to be deternined within the boundaries. Loui sville Home Service uses its Home Service Committee as an advisory body. This Committee is composed of lay members of the community, all of whom are vitally interested in the program. It has become strong since the war expansion of the program. (Prior to this time, regular meetings of the Home Service Committee were not held, but most problems and policies were discussed and decided by the Executive Comitteo).

The Director brings the problems of Home Service before its committee, and discussions of these problems follow. Out of these discussions arise plans for action and suggestions for improvement of the program. Individual case histories are often used to illustrate a particular problem or indicate needed policies or policy changes. The Home Service Comittee does not rule on matters of policy, but presents their recommendations to the Executive Committee for final decisions and adoption.

The functions of the local Home Service Department are carried out by the Director through the use of three divisions: (1) Intake, (2) District, (3) Staff Service.

The Intake and District Divisions are case working divisions while the Staff Service Division is a service division of the Department. Supervisors of these Divisions are responsible to the Director. Workers assigned to the Division are responsible to the Supervisor

1. Statement by Margaret Woll, personal interview, April, 1944. 
of the Divisions to which they are assigned.

In take case workers serve as office interviewers and

except in emergencies carry on their service by office contacts only. A special oase worker assists the Intake Supervisor in handling emergency telegraph and telephone wo rk and in supervising the volunteer case aides and the case workers assigned to night and week-end duty, and in other designated intake assignments. The Division is responsible for (I) interviewing all persons who come, or are referred to the Home Service office for information, service, or assistance, who are not already an open case with the Agency; and for handling emergency telegraph requests and correspondence not requesting home or reference visits, excepting such emergency visits on Intake which can be made by the Intake Department. (2) Acceptance for service and assistance by the Intake Division of cases which on interview or referral appear to require only short contacts which can be given needed service without home or reference visits. These cases, with few exceptions, can be closed prior to the end of the month in which application is made.

The District Division is composed of the District Supervisor, case workers, stenographers, typists, and clerks assigned to the District Division. The case workers have geographical districts in which they visit and spend about one-half their time in case work contacts outside the office. Functions of the District Division are: (1) carrying all cases needing family service and all cases which cannot be served through short contacts in the Intake Division, (2) carrying full responsibility for all cases requiring hone and 
reference visits, (3) carrying all investigations and requests received from other chapters and agencies, which require continuing service, (4) carrying all cases requiring Red Cross financial assistance with medical or hospital care.

The Staff Service Division is composed of the Supervisor, and all workers, paid and volunteer, assigned to perform duties in connection with Staff Service functions. Its function is responsibility for all activities utilized by the Director's office and other Divisions in promptly and efficiently carrying out Home Service functions -- as, reception desk service, case record room activities, teleprinter service, stenographic and clerical pool, etc.

Home Service responsibility has been determined by National Red Cross, and may be divided into four types of services. It is to be emphasized that at any time one case may, and often does, require several or more of these services.

\section{Services}

Communication and Information Inquiries re: servicemen - Many times families become conoerned if they have not heard from them for some time. They may apply to Home Service to determine the welfare of the serviceman. If he is overseas, Form 2230 is used for obtaining such information. If he is in this country, the information is obtained by direct correspondence with the Field Director at his station.

1. Office Manual, Fome Service Division, Louisville Chapter, American Red Cross. 
Inquiries re: civiliens - Home Service is supplied with Form 1609A for the purpose of instituting inquiries regarding the welfare and whereabouts of oivilians abroad.

Messages - By the use of Form 1616, postal or cable messages may be snet by Red Cross to civilians in enemy or enemy-occupied territory, or a cable message to an officially listed prisoner of war. Other messages may be sent to servicemen, such as messages regarding death and births where E.F.M. service is not available to the family. Information - Application may be made to Home Service for information regarding community resources; regulations of government departments, legislation affecting servicemen, ex-servicemen, and their dependents.

Reporting

Social Histories - Red Cross assists the military authorities by obtaining social history material required for medical treatment. Requests for such a history are received from the field director in a military installation or hospital.

An example of this service is the case of Pvt. C. In March, 1944, Red Cross received a letter requesting a social history. It stated that Prt. C. wes hospitalized in an army hospital because of a "nervous condition." The case worker examined the agency registrations on the case and learned, first, that the patient had failed to at tend school because he had suffered from severe headaches, and was extremely nervous. He had never received medical care for this condition. Other facts learned were that he had been arrested for stealing, and had been discharged from the CCC

1. Expenditionary Forces Message. 
program because of misconduct. The case worker then interviewed Pvt. C's mother. She stated that he had begun having fainting spells when five years old, and had had them since, at intervals. She stated that during a fainting spell he would foom at the mouth, and thresh about. She stated that these spells had gradually become more severe and more frequent. She said that Pot. C. had always liked to be alone, and that he was upset by people. He had never been able to maintain a job for any length of time. Mrs. C. informed the case worker that there was a history of epilelsy in the family and that her son's great-grandmother, gram dmother, and sister suffered from the disease.

Aided in making a diagnosis and plan for Pot. C. by this social history, the army doctors moved to obtain for him a medical discharge from tho Army, with a diagnosis of epilepsy. I

Furlough Investigations - Because of illness or death in his family, a serviceman may request a furlough. Hìs commanding officer refers this request to the Red Cross Field Director, who immediately communicates - usually by telegram - with the local chapter. By an exchange of telegrams, through the two-way flow of Red Cross information from camp to Chapter and back, the necessity of the serviceman's presence at home is verified. In cases of extreme emergency, the Chapter worker may initiate the request for a furlough, and communicate with the Field Director. In cases of emergency, the serviceman may be reached even when on maneuvers or other field duty through the assigned Field Director.
1.
From a Home Service case Record.
2. "Services to the Armed Forces," The American National Red Cross, Washington, D.C., December, 194 I. 
The following example shows how this sebvice may be

carried out.

Pvt. S's sister became critically ill. Wiring him at his camp, his fether discovered that Pvt. S's company had left for oumer maneuvers in a distant state. He at once turned to Home Service. The Chapter wired the Field Director at Prt. S's former camp, who in turn obtai ned information as to the address of Pvt. S.'s new post and when he would arrive. When Prt. S. reached his new post, the Field Director in the maneuver area had all necessary furlough and transportation arrangements made, including the purchase of a railroad ticket. Fvt. S. left for home at once. 1

Office of Dependency Benefits Investigations - The 0.D.B. may request the service of investigation of dependency or social conditions of Class $A$ or $B$ dependents. Army Emergency Relief Investigations - A.E.R. may request the investigation of financial need or other matters, of its applicant. Navy Relief Investigations - The Navy may request the investigation of Financial need of its applicants for assistance.

An example of this service is the case of Mrs. B., wife of a sailor, who was institutionalized because of tuberculosis, and in need of thoracoplasty. The case was referred to Navy Relief Society, which authorized payment of $\$ 125.00$ for the first stage of thoracoplacy, and agreed to consider payment of the second and third atages as the need arose. 2

Investigation of Release from Active Duty - Home Service investigates the need of release of servicemen from active duty for agriculture, over 38 , etc. From a Home Service case record. 2. Ibid. 
Reports for Veterans Administration - The V.A. may request Home

Service to gather information or complete a requested report on $r$

any of its cases.

Other Investigations Requested by Field Directors - Home Service investigates other situations not listed above at the request of

Field Directors concerning dependency discharge and other matters.

An example of dependency discharge investigations is the situation of Prt. A. His brother was found to be seriously ill with tuberçulosis, but refused to be institutionalized at Warerly Hills, because his removal from the home would leave their mother alone. She was quite old, and blind, and needed someone to care for her. Jpon request of the Field Director, Home Service investigated this situation, and reported back its findings.

An example of another type of investigation requested by a Field Director is the case of Sgt. B. In the Field Director's letter, he stated that Sgt. B. was divorced from his wife, who had custody over the child. He stated that Sgt. B. had become concerned when informed that his wife had boarded the child out. The Field Director requested (1) information as to the type of home in which the child was placed, (2) the am ount of time the mother spends with the child, (3) the case worker's opinion as to the child's welfare.

The case-worker visited the mother, and the home where the child was living, and spoke with the child. She reported to the Field Director that the mother had been forced to place the child in order that she might obtain employment. She stated that the home was adequate, and that the child was receiving proper care. 1

\section{Assistance With Government Benefits}

Claims for ex-servicemen and their families - Assistance is given in filing claims, forms for death benefits, disability compensation, or hospitalization, and in letters regarding the status of such claims. 
In the preparation of compensation and pension of disability claims of the veteran, and claims for compensation or pension based on the death of a veteran of any war or of peacetime service for the widow, child, dependent mother or father, responsibility to the client included the following: (I) assistance with completing the form for application provided by the Veteran's Administration. (2) assistance in obtaining necessary evidence to complete the claim, including necessary affidavits, employment records, and relationship and dependency evidence. A Power of Attorney form must be signed by every claimant who wishes the assistance of the American Red Cross in presenting a claim to the Veteran's Administration. This form designates power of attorney to the American Red Cross rather than an individual worker or chapter. Thus any accredited representative of the Red Cross. 1 may represent the claimant. Benefits - Families of active servicemen are given assistance in filling out forms for allowances, allotments, insurance, or in follow-up of such benefits. These benefits are, of course, based on the military service of the servicemen.

\section{Family Service}

Financial Assistance - The local policy of Red Cross financial assistance towards dependents of servicemen and ex-servicemen is as follows: (a) Red Cross will provide financial assistance 1. "Preparation of Compensation and Pension Claims," American Red Cross, September, 1943. (Mimeographed) 
to meet basic maintenance needs during the period pending receipt of Class $A$ and $B$ Family Allowance, and in unusual situations, Class E allotments. Red Cross responsibility begins when need is established provided the applicant has filed or wishes to become actively engaged in trying to obtain allotment or family allowance. (b) Dependents requiring finencial assistance after benefits are received, and families denied benefits, will be given information regarding community resources, and help when needed in securing the assistance required.

Where other resources are available, Red Cross will. assume financial responsibility for that limited period pending assumption of responsibility by the other agency; the period of time to be determined through local agreement with that agency. Where no other resources are available, Red Cross may assume financial responsibility for a limited time - that period to be determined by the Chapter as Chapter policy, unless or until National Headquarters establishes a definite period of responsibility. (c) Red Cross will assist in meeting special and nonrecurring needs of servicemen and their dependents through referral to common resources, or in the absence of such resources, through its own fund.

The local policy of assistance to ex-servicemen and their dependenta is: (1) Red Cross will provide financial assiatance to meet basio maintenance needs during the period pending the receipt of benefits - as, pension, insurance, etc. - or pending the initial unfarorable adjudication of a claim. 
Red Cross responsibility begins when need is established provided the applicont for assistance comes in the general category of those potentially eligible for benefits, and provided he had filed or wishes to become actively engaged in filing a claim. When financial assistance is given by Homo Service, the Chapter is to follow the progress of the claim with the Red Cross Field Director stationed at the Veteran's Administration. (2) Ex-servicemen and their dependents requiring financial assistance after benefits are received, are given information regarding community resources, and help when needed in securing the assistance required. (3) Red Cross assists in meeting special and non-recurring neods of this group through referral to community resources, or in the absence of such resources, through its own funds. Following the receipt of benefits the period of responsibility for special needs in those instances in which other resources are not available, will be determined by the Chapter as Chapter policy, unless or until National Headquarters establishes a definite period of responsibility. (4) Ex-servicemen and their dependents requiring financial assistance after the initial unfarorable adjudication of their claim will not be eligible for Red Cross financial assistance. Red Cross will help them by giving information regarding other resources.

Basic maintenance, as used by the Chapter, includes food, clothing, shelter, fuel, utilities, and medical supplies as gauze, cotton, and small drugs.

1. "Office Manual," Home Service Department, Louisville Chapter, American Red Cross. 
It has been discovered that the budget guide prepared by the Council of Social Agencies is inadequate for the families assisted by Red Cross. The standard of this budget guide is figured to apply to the usual dependent group, who have become accustomed to manage on a minimum allowance. Soldiers' wives for a large part find it impossible to manage on the figures set up. The inadequacy has been discussed with the dietician of the Council of Social Agencies, and plans are being devised to revise the budget. Meanwhile, the social workers at Home Service are giving assistance according to individual needs, and with a casework approach. Most relief cases are short-time cases only, until the allotment has been received, or until adjudication of the pension application has been made. Louisville Red Cross financial assistance is adequate in most cases, and generous in some.

It should be noted that careful budgeting must be done in assisting clients with application for Class B allotments, for herein will depend the anount of the allotment, or even if there is to be given an allotment.

For guidance of the case worker in figuring the allotteo's income as against his expenses, the Budget Sheot was prepared by the Director, and presented to the staff in January, 1944, to be used in all Class B applications. 3 Expenses are determined from

1. Miss Mildred Neff.

2. Statement by Miss Margaret Woll, personal interview, April, 1944.

3. See Appendix. 
the applicant's statement of each expenditure, rather than from

a budget standard. This insures a fair decision by the office

of Dependency Benefits.

Family Counseling - Home Service is a case-working agency, and

offers its services to servicemen, ex-servicemen, or their dependents,

in helping with family or personal difficulties. This includes

letters to Field Di rectors requesting interviews with the serviceman

relative to his family situation.

For the active serviceman and his family, the problems

often have to do with his removal from the hame. For the veteran

and his family, there arises a host of problems in making the re-

adjustment to civilian life. For Pvt. Fo counseling service offered

by the case-worker enabled him to return his post happy in the

knowledge that his family problems had somewhat resolved themselves.

Pvt. F. came to Home Service, obviously upset

and extremely agitated. He informed the asse-

worker that he had obtained an emergency furlough

from his Field Director as he was so upset over

his family difficulties, that he could not attend

to duty. He said that his mother had written

stating that his father was keeping company with

another woman, and she had filed for a divorce.

In talking with the soldier, the case-worker

realized that this was not the real problem of his.

His father had long been unfaithful, and his mother

had for some time been contemplating divorce. Rather,

the real problem was the soldier's fear that his wife

no longer cared for him. He stated that she had

suddenly begun writing only occasionally, and that

her letters were "cold." He said that on his recent

furlough home, she had refused to have relations with

him and had cried with no provocation. An appointment

was arranged for Mrs. F. to come into the office. In talking with the case-worker, she said that following her husband's induction, she had had to obtain employment, and had been leaving her child with neighbors. She said that the responsibility of working, keeping 
the home, and worrying over her child was too much for her to carry. The case-worker arranged for her to place the child in a day nursery and suggested weekly conferences with Mrs. F. She seemed happier after the initial interview, and pleased to have someone to help her. The soldier returned to his station with an understanding of his wife's problem, and the knowledge that she would receive guidance and help. 1

Vocational Rehabilitation Planning - Red Cross offers referral service for this need. There are two programs available for rehabilitation to the veterans of this area - the Federal program and the State program partially financed by the Federal government.

On March 24, 1943, Congress passed a law providing for rehabilitation of disabled veterans. It defined eligibility as ... any person who served in the active military or naval service at any time after December 6 , 1941, and prior to the termination of the present war, who is honorably discharged therefrom, and who has a disability incurred in or aggravated by such service from which pension is payable under laws administered by the Veteran's Administration, and is in need of vecational rehabilitation to overeome the handicap of such disability.

The Adninistrator... may utilize and extend existing Veteran's Administration facilities and utilize those of any other governmental agency as well as those maintained by joint Federal and State contribution and in addition, he may, by agreement or contract with public or private institutions or establishment, provide for such additional trai ning facilities as may be suitable and necessary to accomplish the purposes.

The purpose of rehabilitation is to restore employability lost by virtue of a handicap due to service - incurred disability. The Administrator shall ... cooperate with and employ the facilities of other governmental and state em- 
ployment agencies for the purpose of placing

in gainful employment persons trained. 1

Because the Federal program requires a $10 \%$ serviceconpected disability, and because of a lack of flexibility in interpretation of what constitutes a vocational handicap, many veterans are denied assistance under the program. They may then apply to the Kentucky State Vocational Program for rehabilitation.

The state program is the outgrowth of the Federal Civilian Relief Act of June, 1940. This made avai lable to the states funds for the vocational rehabilitation of physically handicapped people of employable age. As the program now operates, the Federal government pays the full cost of administration, onehalf to cost of training, and provides for the other services. The State pays one-half the cost of training and administers the program. Its responsibility extends to all residents of Kentucky, of employable age, who are handicapped (mentally or physically). It further includes non-residents, if they are injured while employed in Kentucky

The program provides for vocational training using facilities wherever the desired training is available; and can set up training facilities if there is the need. Training is provided regardless of financial status. However, if there is a need, the program is equipped to provide maintenance during training, plus the purchase of

1. Lewis, Elmer A. (Compiler) "Laws Pertaining to Veterans," (Public Law 16, 78th Congress). March 24, 1943. 
appliances, as artificial limbs, etc., and for medical care. Finally, the program achieves the ultimate goal of vocational rehabilitation by providing placements for its trainees. Both programs are available for application by veterans. The State Program, however, requires that the veteran with a service-connected disability first make application fior vocational rehabilitation with the Veteran's Administration. If this is denied to the veteran, he may then apply to the State program. The State progrem is more flexible and allows for loose interpretation of "vocational rehabilitation."

Home Service provides the counseling of vocational rehabilitation resources, assists with application to the Veteran's Administration vocational program, or refers to the State program, plans for and with the fomily during the veteran's period of training, and finally interprets the provisions of the law.

Medical Care - Home Service assumes the f'inancial responsibility of medical and hospital care for non-resident dependents of servicemen, when no other arrangements can be made for this care. Referral to Other Agency - the Home Service worker is acquainted with conmunity resources. By drawing skillfully upon the services rendered by public and private agencies, she is able to develop a well-rounded plan of treatment for a family's problem, always bearing in mind, however, that there are special features of Home 
Service which require direct action by the Chepter itself. 1

After determining the other agency resources available to meet the client's needs, Home Service responsibility extends to arranging for referral to the agency; as, filling out application, or telephoning to explain the situation and arranging an appointment for the applicant.

\section{Disaster Relief}

A disaster is a situation, usually catastrophic in nature, which plunges numbers of persons into helplessness and suffering, end, as a result, into need for food, clothing, shelter, medical care, and ather basic necessities of life. In such a situation the National Red Cross is charged by the provisions of its charter with the authority and obligation "to continue and carry on a system of national and international relief... and to apply the same in mitigating the sufferings caused by pestilence, famine, fire, floods, and other national calamities, and to devise and carry on measures for preventing the same." Both by official and by moral mandate it is under obligation to meet promptly and efficiently the needs resulting from disasters.

All responsibility for disaster relief rests first with the local Red Cross Chapters. Only when the resources of the local chapter cannot meet the need of the situation, is the national

1. "Services to the Armed Forces," The American National Red Cross, Washington, D.C., December, 1941.

2. "Disaster Relief," American Red Cross, (Nimeographed). August $30,1943$. 
organization of the Red Cross called upon for help.

In Louisville, Home Service has assumed the responsibility of investigating and planning for victims of individual, or small disasters; as, fire destroying a home, or apartment building. Although Disaster Relief is not a Home Service function, Home Service has been so designated because it has a case-working staff, and is equipped for office and home interviewing.

Prior to January 19, 1943, the Home Service Cormittee was the advisory body for disaster cases. At its meeting on this date, it was decided to organize a small sub-committeo which would be available to study problems of disaster cases and to serve in an advisory capacity on individual disaster cases; as, families with losses of property by fire or other individual incidents. It was stated that expenditure of fairly large amounts of money was sometimes involved, and some advisory group should be available to study these problems and advise the staff. ${ }^{1}$ The sub-comittee was selected.

In rendering disaster relief, a number of policies are followed: (1) relief is given only to disaster sufferers, (2) relief is based on need, not loss; it must never be considered as a reimbursement or as the settlement of a claim or as an attempt to replace anything; it is aid given to those who are in need as a consequence of the disaster and who are unable themselves to meet

1. Minutes, January 19, 1943. 
this neөd, (3) insofar as possible, all relief expenditures made by the Red Cross are kept in the normal channels of trade in the affected area, (4) Red Cross does not assist large commerical or industrial concerms or charitable organizations.

The disaster relief program allows for two types of assistance -.. emergency relief and rehabilitation aid. During the emergency period the Red cross supplies medical aid, food, clothing, and shelter to those in need of such aid. In the work of rehabilitation following disaster, the Red Cross may maintain the family through the period of adjustment, and repair or rebuild homes and provide medical and nursing care, clothing, household furmishings, livestock and occupational equipment and supplies for disaster sufferers whose rehabilitation cannot be effected through their own efforts and resources. Rehabilitation aid is always given on an individual or family basis in accordance with standerd case work practices.

During 1943, Louisville Home Service Department helped sixty-one families needing emergency assistance due to hardships resulting from fire, the March flood, etc. Assistance of $\$ 5,069.98$ was given for emergency assistence, household furnishings, and clothing, and in several cases for some builaing repairs. Funds for Disaster Relief Service to individuals are not Home Service Budget Funds, but are from a special fund set up in the Chapter espocially for disasters.

\section{Tbid.}

2. Monthly Report Home Service Department, Louisville Chapter, American Red Cross, December, 1943. 
All cases of expenditure for Disaster Relief are presented to the Disaster Comittee for approval of plan. However, cases involving expenditure of less than 100.00 may be given assistance at the discretion of the Director, and is then presented to the Disaster Committee at their following meeting. This prevents delay of needed assistance for the client, and allow: for better service to the disaster victim. 1

1. See appendix for the outline used for guidence to the case worker in preparing her disaster case for approval. 
CHAPTER V

PROBLEMS OF HOME SERVICE, AND CONPARISONS WITH OTHER AGENCIES 


\section{CHAPTER $V$}

PROBLEMLS OF HOME SERVICE, AND COMPARISONS WITH OTHER AGENCIES

\section{Problems:}

In evaluating the work of Home Service, it is mecessary to consider, first, its problems and how they are being met, and second, to compare the work, services, and problems of the Louisville Chapter with that of similar agencies. Indianapolis, Indiana, and Dayton, Ohio, were chosen for these comparisons because of their similar size and equal proximity to army camps.

The most serious problem which has been faced by Home Service, and which has not yet reached a satisfactory solution, is that of medical and hospital care for its non-residents. As 1

indicated, the sub-committee of intake has been active in working towards solution. The Home Service Committee, too, has spent much effort in trying to revoke the decision of the Health Department; and in trying to solve other problems arising in regard to medical care of its clients. In some directions, better understanding between the two agencies has been achieved, but much is yet to be done. At its meeting on April 20, 1943, the Home Service Committee was concerning itself with the refusal of the General Hospital to admit patients unless residents of Louisville ... even with authorization of payment by Red Cross. As a result, these patients had to be hospitalized in private hospitals. This

1. See Chapter III 
increased the cost, because with private hospitalization, the doctor's fee must also be paid. The situation seemed particularly strange to the committee because the General Hospital was not filled to capacity, while the private hospitals were heavily overburdened. A sub-conmittee was appointed to deal with the problem. On May 18, Miss Brandeis, chairman of the sub-comittee, reported that her cormittee had met with Dr. Leavell. She stated that an agreement had been reached whereby non-residents might be admitted to the General Hospital at the same fee that was paid to private 2 hospitals. The following month, attention was brought to a case on which the General Hospital was requesting payment of a bill, and in which American Red Cross had not been aware of the situation, and had not authorized care. An agreement was reached with Louisville General Hospital whereby Red Cross was not to be billed unless previous arran gements for payment had been made with the agency. In July, 1943, the General Hospital issued several requests that Red Cross pay for hospitalization of its resident cases. This resulted in a meeting between the two agencies. The "Statement of Policy" issued following this meeting asserted:

(1) American Red Cross funds were to be used to provide medical and hospital care for those to whom such care was not available from taxsupported facilities (non-residents).

(2) All residents of Jefferson County were oligible for care at the General Hospital, and

1. Minutes, April 20, 1943.

2. Ibid, May 18, 1943. 
those for financial assistance with medical and hospital care, were to be referred to the General Hospital.

(3) Home Service was to pay for hospitalization and medical care on those cases for which it authorized such care. Referrals and authorizations were to be given in writing. Authorizations were to be specific as to the limitations of authorized care. The General Hospital was to submit an itemized bill to the patient, or the family with whom the agency would make arrangements for meeting the bill.

(4) Emergency care was to be given non-residents referred by Red Cross.

(5) Red Cross assumed no responsibility for the non-resident dependent of a servicemen, if such non-resident did not reside in Jefferson County。 1

On September 14, 1943, Dr. Leavell invited the Sub-

Committee appointed by Home Service to meet with him for the purpose of discussing individual cases on which questions of payment had arisen. Twelve cases were considered. Seven were found to be the responsibility of agencies other than Americon Red Cross, and the Louisville General Hospital agreed to look to those agencies or the respective families. Three cases were continued, in the process of further investigation. One case was to be referred by the Louisville General Hospital to the Department of Law of the City of Louisville because of an alleged misuse of family allotment checks. One case considered found the family making satisfactory payments on the account. 2

I. Ibid, July, 1943.

2. Minutes of meeting between Sub-Committee of Home Service, Louisville Chapter, American Red Cross, and Dr. Leavell, Director of Louisvilie and Jefferson County Heaith Department, September 14, 1843. 
At its meeting on September 21, 1943, Home Service considered a case presented by a staff member, in which the non-resident wife of a sailor had been hospitalized at Louisville General Hospital, by authorization of Home Service. The hospital had done much experimentation with the patient's condition as a form of learning to the medical students, thus accumulating a large bill for laboratory fees and X-rays, and other extras. The committee questioned the value of these tests in actual treatment for the patient and recommended discussion of possible reduction of the bill by the hospital. The sub-comittee met with Dr. Leavell, who reported that no reduction could be made, and the full amount was paid.

Table IX

Expenditures for Medical and Hospital Care, Louisville Home Service Department, 1943.

\begin{tabular}{l|c|c|c|c}
\hline & $\begin{array}{c}\text { Non- } \\
\text { Residents }\end{array}$ & $\begin{array}{l}\text { No. of } \\
\text { Cases }\end{array}$ & Residents & $\begin{array}{l}\text { No. of } \\
\text { Cases }\end{array}$ \\
\hline $\begin{array}{l}\text { Private Hospitals } \\
\text { Private Doctors }\end{array}$ & $502,998.51$ & 48 & $\$ 1,944.75$ & 34 \\
$\begin{array}{l}\text { Louisvilie General } \\
\text { Hospital }\end{array}$ & $4,458.54$ & 18 & 351.00 & 10 \\
\hline TOTAL & $\$ 7,959.05$ & (unknown) & $-0-$ & (unknown) \\
\hline
\end{tabular}

A. "Report of Expenditures for Medical and Hospital care," Claendar Year January 1, 1943, through December 31, 1943, Louisville, Kentucky•

B. The Total amount paid during the year for medical care was $11,028.90$. This amount included 774.10 for other professional services, as: drugs, appliances, ambulances, etc.

1. Minutes, September 21, 1943. 
Table IX indicates the large amount of money paid for medical care by Home Service. The explanation given by the agency for paying private hospital and doctor bills for residents was (1) the patient was already hospitalized when Red Cross was contacted for assistance with the bill, or (2) the private doctor attending recommended hospitalization and stated that it was necessary to the patient's welfare that he continue the treating the patient, or (3) the patient was ineligible for Louisville General Hospital because of alleged personal resources.

It is to be noted that no instances have been found wherein the client has failed to obtain needed medical care or hospitalization from Home Service because of controversies with the Louisville General Hospital. Home Service has in each case assumed the burden, while working towards a better understanding with the General Hospital, and while working towards a reversal of the Law Department ruling towards 1

"technicel" non-residents.

The Director of the Home Service Division of the Indianapolis, Indiana, Chapter, states:

I do not believe that the problem of girls who are residents of Indianapolis marrying non-resident soldiers has created any serious difficulty. To my knowledge our City Hospital has not refused them medical care. We have on a case work basis provided medical care in private hospitals, with private doctors in various instances...sometimes because the patient is non-resident, sometimes because it was the better plan. To date, this Chapter has not requested any Army Emergency Relief reimbursements, but we have

1. The term "technical non-residents" has been informally adopted to indicate Louisville residents marrying non-resident servicemen. 
worked out plans in cooperation with Navy Relief, at their request, where Navy Relief has paid hospital and doctor bills.

Local private hospitals and the Indiana University Hospitals have been most cooperative in giving discounts as have our physicians. One of our leading surgeons sends no bill when he knows Red Cross is responsible for payment.

Through a state plan we are able to provide medical care for children from one to ten years at Riley Hospital, one of the Indiana University Hospitals. This care is available to both resident and non-resident service connected cases. For specific types of care, such as treatment of venereal disease, we have referred patients to the Isolation Hospital, or City Clinic and hospital, which is not concerned with residency. 1

On this subject, the Director of the Dayton, Ohio, Home

Service Department states:

As in most communities which adjoin large Army installations Dayton faces the problem of local resident girls marrying non-resident seivicemen to a considerable extent. They do, of course, lose their legal residence, but this has not affected the plan for medical care materially. All referrals for free medical care, including hospitalization are made through one agency, the Hospital Admissions Bureau。

The only group not eligible for care are residents of Ohio of a county other than Montgomery. Residents of other states are eligible. Where medical care is needed by a member of the group ineligible for public service the Chapter has assumed the responsibility as a special and non-recurring need. During recent months these cases have in a few instances, been referred to Army Emergency Relief. 2

1. Letter from Mrs. Eleanor Dunn Moore, Di rector, Home Service, Indianapolis, Chapter, American Red Cross, Indianapolis, Indiana, July 14, 1944。

2. Letter from Miss Alice Culter, Director, Home Service Department, Dayton Chapter, American Red Cross, Dayton, Ohio, July 28, 1944. 
Another problem faced by Home Service is that of supplementation of allotment checks. Although committee action on September 1943, decided against regular supplementation, and this decision was later upheld by the Area office, and National Red Cross policy has fallen in line with this action, Home Service is still confronted with the problem of what to do in such situation. It is particularly pressing in cases in which a serviceman's wife, receiving only $\$ 50.00$ per month, is unable to work and has no other resources; a serviceman's wife with one child, receiving $\$ 80.00$ per morth and unable to work; and of families accustomed to a very high standard of living. Neither the Municipal Bureau of Social Service nor the State Department of Welfare will accept them for assistance as their budget is covered by the amount of the allotment. Home Service has given these fomilies assistance in budgeting and planning, and often has met special, non-recurring noeds. However there remains much hardship and deprivation existing amorg this group.

of this problem, Indianapolis states:

We have had several families unable to manage on their government allowances and we have supplemented in cases of emergency. We have endeavored through family counseling to assist these families to adjust. For the most part there are no other resources to assist such families. The Township Trustee who is responsible for general public relief will not accept them. The Department of Public Welfare does not accept such cases for categorical assistance except in some instances where the Class B Allowance does not meet the amount allowed by the Department of Public Welfare. I think the problem is more noticeable in smaller families...probably a wife with one child. As to families of higher economic level; the initial adjustment is frequently difficult but for the most part 
they seem better able to manage than some families who have no experience in handling money and who are receiving more than they ever had before. Of course labor is at a premium here and many of our wives and mothers are working and supplementing their allowances, but the wife who is unable to work is not able to put much aside for emergencies.l

The Dayton Chapter states:

Many cases come to our attention in which the problem is inability to manage on the Family Allowance. Most of these are small femilies and or those of higher economic levels. Both Aid to Dependent Children and the Dayton Department of Public Assistance are able to accept many of these cases for supplementation of the Allowance. Where problems of family relationships are involved the Family Welfare Association will occasionally accept such a case. In some other instances we have found it possible to relieve the problem by consultation, sometimes working with the family for a considerable period on a case work level. 2

The question of cashing personal and allotment checks, and money orders has been a perplexing problem to Home Service. In the case of servicemen's wives, who have followed their husbands to Louisville and are new to the community, they have not established credit, and cannot get their allotment checks cashed. If the case is active with Home Service, and the Case-worker can identify the client, the agency will cash the check. If the person is unknown, however, such service will not be given. There are instances where it has been several days before these individuals have been able to obtain cash for their checks and hardship has resulted.

1. Letter from Mrs. Eleanor Dunn Moore, Director, Home Service, Indianapolis Chapter, American Red Cross, Indianapolis, Indiana, July $14,1944$.

2. Letter from Miss Alice Cutler, Director, Home Service, Dayton Chapter, American Red Cross, Dayton, Ohio, July 28, 1944. 
A number of instances have arisen whereby a serviceman overseas has converted his money into Honey Orders payable to himself and mailed them home for safe-keeping. Upon returning home, he has attempted to cash them, and been unable to do so because they were in effect for over sixty days. This has necessitated returning of the Money Order to the place of issuance, and a delay of some time before they were reissued. Where the servicemen--or in several cases the discharged serviceman--had been depending on these funds, he has suddenly found himself without resources. To date, Home Service has not been called upon to assist financially such situations, but it is quite conceivable that they may have to do so.

Many times servicemen have applied to Home Service requesting that the agency cash a personal check so that they might have resources to return to their station, having either lost or spent all of their money. The Louisville Chapter will not give such a service, but will contact the Field Director at the serviceman's station, and request authorization of a loan to the serviceman, to be repaid by him to the Field Director at his post; the Field Director reimbursing 2 the Chapter. The procedure of the Indianapolis Chapter in such a situation is to "accept the serviceman's check in exchange and advise him we consider it a loan until his check clears the bank. To date, we have had no losses."

1. Personal interview with Miss Margaret Woll, Director, Home Service Division, Louisville Chapter, American Red Cross, Louisville, Kentucky, April, 1944.

2. This is the usual procedure for making a loon for any reason to active servicemen. 
The problem of the extent to which Red Cross should be drawn into questions of establishing the legal rights of dependents of servicemen has been considered by the Home Service Comnittee. At its meeting in september, 1943, a case was presented of the mother was of an active serviceman who/partially dependent on the $\$ 37.50$ allotment received from him. She had been supplementing this by running a rooming house, and had recently been evicted. Her lawyer had come to Home Service for help in bringing pressure for a new trial because he felt her rights under the Soldiers and Sailors Civil Relief Act had not received proper consideration and that the Office of Price Administration had been in error when they allowed an eviction notice to be served on her. The Comnittee ruled that Red Cross could not take part directly in the prosecution of any such case regardless of the fact that the legal rights of dependents of servicemen are involved. On this basis, all such situations are referred to the makes such a decision readily understandable. However, failure to extend its aid and influence in all legal matters might conceivably mean a failure to meet all the needs of the eligible client. An ever-present problem of Home Service is the frequent turnover in personnel; a problem of most chapters and many social agencies. The transiency caused by the war, the increased opportunities for social workers in more lucrative placements, and the tempting higher wages offered by war industries, have all served to cause rapidly changing personnel among the staff, with all its attendant 
problems. Salaries of Home Service are meeting those paid by other agencies in the community.

Because of a shortage of trained social workers, the

staff is composed of some persons with graduate degrees, a number with some graduate training, a few with previous social work experience plus a college degree, and a number with only a college degree. The staff is urged to take courses at the University of Louisville, School of Social Work, and a number of them are doing so. Because of the pressure of the work and lack of facilities, there is no chance to give incoming staff members an "In-Service Training Course."

The following are statements of other chapters in regard to personnel. Detroit, Michigan, states:

We have all varieties of training represented on our staff. We are taking girls on the staff who have finished college, and assigned them as case aides. These girls are getting an "in service" training similar to what one would get as a student in a school of social work, except that they carry much larger case loads. Others on our staff have field work and approximately one year of graduate training, and some have their graduate training. 1

Indianapolis states:

We have tried to secure persons who are college graduates, who have had experience in the field of social work, and who have had some formal training. We have had to take come persons who have no practical experience and we have done some training on the job with these persons. We have been handicapped because our salaries do not compete with salaries of the other agencies in Indianapolis. 2

1. Letter from Leon B. Gridley, Director, Detroit Chapter, Home Service, American Red Cross, Detroit, Michigan, Dec. 8, 1943.

2. Letter from Eleanor Dunn Moore, Director, Home Service, Indianapolis Chapter, American Red Cross, Indianapolis, Indiana, Jan. 5,1944. 
Dallas states:

Only one (of our staff) has had professional training; three of them have had no regular previous paid case work experience; the other three have had varying degrees of related experience. 1

San Francisco states:

We have not had any special difficulty in getting experienced case workers. If within the next year it is necessary for us to hire inexperienced personnel, we will try to take on a group of potential case aides and set up a training program for them. 2

Minneapolis states:

We have a staff of nine professional people, four of whom have completed groduate training. The others have had considerable experience in case work。 3

Nashville states:

Our staff is varied. Some are non-professional, sone have a college degree with no social work training, while others have one or two years of social work training. 4

Finally the constantly growing case load and the pressure of the job are major problems with which the agency will probably be faced for a long time to come.

1. Letter from Claire L. Moore, Home Service Secretary, Dallas Chapter, Anerican Red Cross, Dallas, Texas, December 29, 1943.

2. Letter from Aileen G. Steele, Director, Home Service, San Francisco Chapter, American Red Cross, San Francisco, California, December 22, 1943 .

3. Letter from Alice S. Whelan, Di rector, Home Service, Hennepin County Chapter, American Red Cross, Minneapolis, December 13, 1943.

4. Letter from Ruth E. Moore, Executive Di rector, Nashville-Davidson County Chapter, American Red Cross, Nashville, Tennessee, December $6,1943$. 
Comparisons Between Louisville Home Service, and Home Service of Dayton and Indianapolis Chapters.

Louisville Home Service finds it within its financial

policies to provide, in some instances, financial assistance where the case work services are carried by other agencies. This allows for provision of a fuller service to the olient. The agency recognizes that with the pressure of the work, it is sometimes not possible to follow a situation as closely as the situation indicates, and may refer it to another working agency.

Such a situation occurred in the case of the three adolescent children of Mrs. B., a widow, who was receiving full support of herself and children from the al lotment of her son in the Navy. The oldest child, 16 years old, applied for assistance when, upon the death of the mother, they were unable to cash the allotment check because it was made out in her name. The children were keeping house together without supervision, and the advisability of such a plan was questioned. They were referred to family Service Organization for supervision, help in planning and budgeting, while receiving assistance from Home Service until the allotment might be obtai ned for them.

The policy of the Indianapolis Chapter is:

On the whole we do not consider it a good case work plan to provide financial assistance when another agency is giving the case work service. This is true in the case of family agencies. If they accept a case for service, they generally agree to accept all responsibility. We did have one such case carried with Catholic Charities, but felt it an unsound plan. of course, for special types of service such as child care and guidance, medical care, of nursing, mental hygiene, etc., we do provide financial assistance while the proper agency give the case work service. 1

Dayton's policy states:

This chapter has not adopted the policy of giving

1. Letter from Mrs. Eleanor Dunn Moore, Director, Home Service, Indianapolis Chapter, American Red Cross, Indianapolis, Indiana, July 14. 1944 . 
financial assistance while case work service is being given by another agency. We feel that we are fortunate to have on our staff sufficient number of trained and experienced case workers to enable us to render adequately whatever case work service may be indicated. 1

The Sub-Committee on Intake of the Council of Social Agencies is the co-ordinating group in Louisville working to deal with the many problems of the men now being discharged fram the services. Red Cross plays an active part in this group. There has not yet been formulated plans for establishment of a Central Information Center for these returning veterans. There is a need for such a development.

\section{In Indianapolis:}

There is developing under our Council of Social Agencies a referral and information center which will be open to all persons including veterans. This is not yet functioning. There is also in process of development a state group made up of United States Employment Service, Selective Service, Veterans' Administration, Veterans' Organization, and Red Cross. 2

In Dayton:

There is a co-ordinating group in this community which is concerning itself with post-war planning and plans are under way, under its auspices, for establishing a veterans information and referral center. It is expected that this office will open within a few weeks. 3

In hours of service coverage the Louisville Chapter compares favorably with the agencies examined. In Indianapolis, the office

1. Letter from Miss Alice Culter, Director, Home Service, Dayton Chapter, American Red Cross, Dayton, Ohio, July 28, 1944.

2. Letter from Mrs. Eleanor Dunn Moore, Director, Home Service, Indianapolis Chapter, American Red Cross, Indianapolis; Indiana, July 14, 1944.

3. Letter from Miss Alice Culter, Director, Home Service, Dayton, Chapter, American Red Cross, Dayton, Ohio, July 28, 1944. 
is open from 8:30 a.mo until 10:00 p.m. Mionday through

Saturdey and from 9:00 a.m. until 6:00 p.m. on Sunday. They have recently employed a case worker to be on duty from 6:00 $\mathrm{p} \cdot \mathrm{m}$. to 10:00 p.m. nightly, and the staff take turas working on Sunday and holidays.

One of the supervisors, or the Director, is on call every night and on Sunday. From 10:00 p.m. until 8:30 a.m. on week nights and from 6:00 p.m. until 8:30 a.m. on Sundays the Indianapolis Chapter uses a telephone answering service for which they pay $\$ 25.00$ per month. The Telephone Company does a screening job and calls the worker who is on duty at home (one of the supervisors or the director) on emergencies and wires. In this way, they provide a twenty-four hour service. In Dayton, the agency is open from 8:30 a.m. to 11:00 p.m. daily. It has a regular staff member employed to work from 6:00 p.m. to 11:00 p.m. each night. According to the Director, the volume of wires received after 11:00 p.m. is not large and is shared by two Supervisors, who take the calls at home. The Department is open all day on Saturday, and on Sunday is covered by the regular case workers on a rotating basis. The Louisville Chapter is open from 9:00 a.m. to 9:00 p.m. on Sundays, and from 8:30 a.m. to 10:00 p.m. daily. An attempt has been made to establish a telephone answering service in Louisville similar to that used by the Indianapolis Chapter. However, the Telephone Company is unable to offer such a service. Western Union has the telephone numbers of several members of the staff, and has contacted them when they have deemed a wire urgent. 
Adjoining camps also have the telephone numbers of several staff members, and may contact them if necessary.

In expansion of personnel and quarters, Louisville Home Service may again be compared favcrably. Indianapolis reports that their quarters have grow from three rooms, until they now occupy the major part of the whole floor of a large office building. Dayton reports that they have found it necessary to expand space provided for the Department in accordance with the increase in staff.

Table $X$, on the following page, indicates the expansion of personnel, among the agencies examined, as a result of the war. Table XI, on the following page, is a comparison of cases handled by the three agencies from July, 1943 through April, 1944. Tables XII, XIII, XIV, and XV, on succeeding pages, give a comparison of some of the services given by the three agencies 2

examined. From these tables, it can be seen that in volume of services, Louisville has done a bigger job than has either Indianapolis or Dayton. In almost every kind of assistance offered, Louisville has given a greater volume of service.

1. See Chapter II for a discussion of expansion in quarters of Louisville Home Service Department.

2. Some of the variations in numbers of the various services given by the agency is because of the differences in interpretation between agencies of the categories. 
Table X

Expansion of Personnel, Indianapolis, Dayton, and Louisville Home Service Department, 1941 and July, 1944.

1941

\begin{tabular}{l|c|l|c}
\hline Personnel & Indianapolis & Dayton & Louisville \\
\hline Executive Secy & 1 & 1 (Part Time) & 1 \\
Case Workers & 2 & 0 & 4 \\
Clerical Workers & 3 & 0 & 5 \\
\hline TOTAL & 6 & 1 (Part Time) & 10 \\
\hline
\end{tabular}

July, 1944

\begin{tabular}{l|c|c|c}
\hline Personnel & Indianapolis & Dayton & Louisville \\
\hline Director & 1 & 1 & 1 \\
Supervisors & 4 & 3 & 5 \\
Case Workers & 19 (Total) & 15 (Total) & 25 (Total) \\
a. Full Time & 19 & 7 & 18 \\
b. Part Time & 0 & 2 & 4 \\
c. Volunteer & 0 & 6 & 3 \\
Clerical Workers & 17 (Total) & 28 (Total) & 55 (Total) \\
a. Full Time & 17 & 6 & 13 \\
b. Part Time & 0 & 2 & 7 \\
c. Volunteer & 0 & 20 & 35 \\
\hline TOTAL & 41 & 47 & 86 \\
\hline
\end{tabular}

Table $X$ indicates the expansion in personnel in the agencies examined, as the result of the war expansion of their programs. 
Table XI

Comparison of Cases Handled by Louisville, Indianapolis, and Dayton Home Service Departments, July, 1943 through April,1944.

Intake During Month

Cases Acted on During Month

\begin{tabular}{|c|c|c|c|c|c|c|}
\hline $\begin{array}{l}\text { Year - } \\
\text { Month }\end{array}$ & $\begin{array}{l}\text { Louis- } \\
\text { ville }\end{array}$ & $\begin{array}{l}\text { Indian- } \\
\text { apolis }\end{array}$ & Dayton & $\begin{array}{l}\text { Louis- } \\
\text { ville- }\end{array}$ & $\begin{array}{l}\text { Indian- } \\
\text { apolis }\end{array}$ & Dayton \\
\hline 1943 & & & & & & \\
\hline $\begin{array}{l}\text { July } \\
\text { August }\end{array}$ & $\begin{array}{l}1,381 \\
1,522\end{array}$ & $\begin{array}{l}1,316 \\
1.179\end{array}$ & $\begin{array}{l}510 \\
851\end{array}$ & $\begin{array}{l}1,964 \\
2,153\end{array}$ & $\begin{array}{l}2,008 \\
2,008\end{array}$ & $\begin{array}{l}872 \\
998\end{array}$ \\
\hline $\begin{array}{l}\text { August } \\
\text { September }\end{array}$ & $\begin{array}{l}1,062 \\
1,677\end{array}$ & 1,240 & $\begin{array}{l}597 \\
597\end{array}$ & 2,400 & $\begin{array}{l}2,008 \\
1,937\end{array}$ & $\begin{array}{r}998 \\
1,046\end{array}$ \\
\hline October & 1,654 & 1,237 & 571 & 2,491 & 1,915 & 954 \\
\hline November & 2,096 & 1,519 & 490 & 2,935 & 2,066 & 974 \\
\hline $\begin{array}{l}\text { December } \\
1944\end{array}$ & 1,797 & 1,435 & 765 & 2,718 & 2,099 & 1,289 \\
\hline January & 1,953 & 1,352 & 634 & 2,866 & 2,135 & 1,069 \\
\hline February & 3,342 & 1,385 & 599 & 4,294 & 2,291 & 1,005 \\
\hline March & 2,356 & 1,453 & 649 & 3,245 & 2,292 & 1,096 \\
\hline April & 2,063 & 1,440 & 693 & 2,904 & 2,451 & 1,132 \\
\hline TOTAL & 19,841 & 13,556 & 7,359 & 28,070 & 21,202 & 10,435 \\
\hline
\end{tabular}

* From estimates made by the U.S. Bureau of Census in November, 1943, population of Jefferson County, Kentucky (Louisville Chapter) was 425,528 ; population of Marion County. Indiana (Indianapolis Chapter) was 498,094 ; population of Montgonery County, Ohio (Dayton Chapter) was 341,553 . 1

Table XI illustrates that the Louisville Chapter gave services to a larger number of cases than either of the other cities examined from the period of July, 1943, to April, 1944. The author accounts for these differences: (1) because of the larger army installations around Louisville, (2) because of fewer referral resources in Louisville, (3) a seemingly broader interpretation of eligibility in Louisville Home Service resources than either of the other cities.

1. "Estimated Civilian Population of Continental U.S. by Counties," U.S. Bureau of Census. November 1, 1943. 
Table XII

Comparison of Communication and Information Services by Louisville, Indienapolis, and Dayton Home Service Departments July, 1943 through April, 1944.

\begin{tabular}{|c|c|c|c|c|c|c|}
\hline \multirow[b]{2}{*}{$\begin{array}{l}\text { Year } \\
\text { Month }\end{array}$} & \multicolumn{3}{|c|}{ Inquiries RE: Servicemen } & \multicolumn{3}{|c|}{ Information only } \\
\hline & $\begin{array}{l}\text { Louis- } \\
\text { ville }\end{array}$ & $\begin{array}{l}\text { Indian- } \\
\text { apolis }\end{array}$ & Dayton & $\begin{array}{l}\text { Louis- } \\
\text { ville }\end{array}$ & $\begin{array}{l}\text { Indian- } \\
\text { apolis }\end{array}$ & Dayton \\
\hline $\begin{array}{l}1943 \\
\text { July } \\
\text { August } \\
\text { September } \\
\text { October } \\
\text { November } \\
\text { December } \\
1944 \\
\text { January } \\
\text { February } \\
\text { March } \\
\text { April } \\
\end{array}$ & $\begin{array}{r}117 \\
99 \\
106 \\
88 \\
60 \\
58 \\
\\
79 \\
52 \\
58 \\
51 \\
\end{array}$ & $\begin{array}{l}252 \\
296 \\
376 \\
326 \\
315 \\
580 \\
\\
275 \\
432 \\
527 \\
551 \\
\end{array}$ & $\begin{array}{l}260 \\
135 \\
318 \\
141 \\
124 \\
202 \\
\\
159 \\
189 \\
197 \\
212 \\
\end{array}$ & $\begin{array}{l}383 \\
507 \\
701 \\
712 \\
776 \\
725 \\
\\
791 \\
584 \\
792 \\
680 \\
\end{array}$ & $\begin{array}{r}29 \\
97 \\
38 \\
19 \\
134 \\
56 \\
\\
57 \\
47 \\
72 \\
69 \\
\end{array}$ & $\begin{array}{r}52 \\
38 \\
90 \\
86 \\
163 \\
43 \\
\\
251 \\
240 \\
551 \\
632 \\
\end{array}$ \\
\hline TOTAL & 748 & 3,930 & 1,937 & 6,651 & 728 & 2,146 \\
\hline
\end{tabular}

Table XIII

Camparison of Assistance with Government Benefits Services by Louisville, Indianapolis, and Dayton Home Service Departments July, 1943 through April, 1944.

\begin{tabular}{|c|c|c|c|c|c|c|}
\hline \multicolumn{4}{|c|}{ Claims } & \multicolumn{3}{|c|}{ Benefits } \\
\hline $\begin{array}{l}\text { Year } \\
\text { Month }\end{array}$ & $\begin{array}{l}\text { Louis- } \\
\text { ville }\end{array}$ & $\begin{array}{l}\text { Indian- } \\
\text { apolis }\end{array}$ & Dayton & $\begin{array}{l}\text { Louis- } \\
\text { ville }\end{array}$ & $\begin{array}{l}\text { Indian- } \\
\text { apolis }\end{array}$ & Dayton \\
\hline $\begin{array}{l}1943 \\
\text { July }\end{array}$ & 74 & 85 & 45 & 119 & 96 & 13 \\
\hline August & 57 & 94 & 50 & 164 & 233 & 4 \\
\hline September & 86 & 101 & 36 & 164 & 222 & 19 \\
\hline October & 77 & 102 & 34 & 177 & 183 & 6 \\
\hline Norember & 96 & 108 & 83 & 546 & 272 & 0 \\
\hline $\begin{array}{l}\text { December } \\
1944\end{array}$ & 107 & 76 & 38 & 196 & 203 & 16 \\
\hline Janua ry & 147 & 111 & 59 & 278 & 306 & 10 \\
\hline February & 1803 & 124 & 52 & 346 & 209 & 4 \\
\hline March & 544 & 122 & 66 & 191 & 269 & 28 \\
\hline April & 236 & 121 & 72 & 362 & 325 & 19 \\
\hline TOTAL & 3,227 & 1,044 & 535 & 2,543 & 2,518 & 119 \\
\hline
\end{tabular}


Table XIV

Comparison of Reporting Services by Louisville, Indianapolis, and Dayton Home Service Departments July, 1943 through Ipril, 1944.

\begin{tabular}{|c|c|c|c|c|c|c|}
\hline & \multicolumn{3}{|c|}{ Social Histories } & \multicolumn{3}{|c|}{ Furlough Investigation } \\
\hline $\begin{array}{l}\text { Year } \\
\text { Month }\end{array}$ & $\begin{array}{l}\text { Louis- } \\
\text { villo }\end{array}$ & $\begin{array}{l}\text { Indian- } \\
\text { apolis }\end{array}$ & Dayton & $\begin{array}{l}\text { Louis- } \\
\text { ville }\end{array}$ & $\begin{array}{l}\text { Indian- } \\
\text { apolis }\end{array}$ & Dayton \\
\hline 1943 & & & & & & \\
\hline July & 45 & 42 & 17 & 377 & 495 & 249 \\
\hline August & 37 & 39 & 36 & 363 & 507 & 305 \\
\hline September & 43 & 34 & 34 & 332 & 486 & 312 \\
\hline October & 47 & 55 & 68 & 405 & 528 & 271 \\
\hline November & 46 & 56 & 71 & 380 & 533 & 270 \\
\hline $\begin{array}{l}\text { December } \\
1944\end{array}$ & 33 & 62 & 45 & 556 & 464 & 409 \\
\hline January & 45 & 61 & 38 & 463 & 523 & 363 \\
\hline February & 42 & 60 & 49 & 462 & 524 & 312 \\
\hline March & 48 & 53 & 58 & 472 & 483 & 370 \\
\hline April & 45 & 44 & 41 & 483 & 407 & 424 \\
\hline TOTAL & 431 & 506 & 457 & 4,293 & 4,950 & 3.285 \\
\hline
\end{tabular}

\begin{tabular}{|c|c|c|c|c|c|c|}
\hline \multirow[b]{2}{*}{$\begin{array}{l}\text { Year } \\
\text { Month }\end{array}$} & \multicolumn{3}{|c|}{$\begin{array}{l}\text { Investigations re: } \\
\text { Release From Active Duty }\end{array}$} & \multicolumn{3}{|c|}{ Reports for V.A. } \\
\hline & $\begin{array}{l}\text { Louis- } \\
\text { ville }\end{array}$ & $\begin{array}{l}\text { Indian- } \\
\text { apolis }\end{array}$ & Dayton & $\begin{array}{l}\text { Louis- } \\
\text { ville }\end{array}$ & $\begin{array}{l}\text { Indian- } \\
\text { apolis }\end{array}$ & Dayton \\
\hline $\begin{array}{l}1943 \\
J v 1 \mathrm{y}\end{array}$ & & & & & & \\
\hline $\begin{array}{l}\text { July } \\
\text { August }\end{array}$ & $\begin{array}{r}8 \\
14\end{array}$ & $\begin{array}{l}27 \\
48\end{array}$ & $\begin{array}{l}22 \\
25\end{array}$ & $\begin{array}{l}12 \\
10\end{array}$ & $\begin{array}{r}1 \\
27\end{array}$ & $\begin{array}{l}9 \\
9\end{array}$ \\
\hline September & 12 & 45 & 48 & 6 & 34 & 14 \\
\hline October & 5 & 51 & 37 & 4 & 38 & 11 \\
\hline November & 2 & 34 & 26 & 5 & 35 & 14 \\
\hline $\begin{array}{l}\text { December } \\
1944\end{array}$ & 6 & 27 & 11 & 8 & 33 & 31 \\
\hline Janua ry & 8 & 35 & 18 & 9 & 54 & 11 \\
\hline February & 1 & 33 & 15 & 7 & 52 & 5 \\
\hline March & 0 & 31 & 16 & 0 & 64 & 7 \\
\hline April & 0 & 21 & 18 & 4 & 72 & 11 \\
\hline TOTAL & 56 & 352 & 236 & 65 & 410 & 122 \\
\hline
\end{tabular}


Table XV

Comparison of "Family Service" Services by Louisvillo, Indianapolis, and Dayton Home Service Departments, July, 1943 through April, 1944.

\begin{tabular}{|c|c|c|c|c|c|c|}
\hline \multirow[b]{2}{*}{$\begin{array}{l}\overline{Y e a r} \\
\text { Month }\end{array}$} & \multicolumn{3}{|c|}{ Financial Assistance } & \multicolumn{3}{|c|}{ Family Counseling } \\
\hline & $\begin{array}{l}\text { Louis- } \\
\text { ville }\end{array}$ & $\begin{array}{l}\text { Indian- } \\
\text { apolis }\end{array}$ & Dayton & $\begin{array}{l}\text { Louis- } \\
\text { ville }\end{array}$ & $\begin{array}{l}\text { Indian- } \\
\text { apolis }\end{array}$ & Eayton \\
\hline 1943 & & & & & & \\
\hline July & 180 & 253 & 38 & 571 & 248 & 132 \\
\hline August & 175 & $\begin{array}{l}207 \\
193\end{array}$ & $\begin{array}{l}66 \\
52\end{array}$ & $\begin{array}{l}609 \\
727\end{array}$ & $\begin{array}{l}387 \\
319\end{array}$ & 141 \\
\hline $\begin{array}{l}\text { September } \\
\text { October }\end{array}$ & $\begin{array}{l}154 \\
165\end{array}$ & $\begin{array}{l}193 \\
171\end{array}$ & $\begin{array}{l}52 \\
80\end{array}$ & $\begin{array}{l}721 \\
844\end{array}$ & $\begin{array}{l}319 \\
269\end{array}$ & $\begin{array}{r}94 \\
140\end{array}$ \\
\hline November & 181 & 200 & 65 & 915 & 330 & 150 \\
\hline $\begin{array}{l}\text { December } \\
1944\end{array}$ & 210 & 270 & 84 & 891 & 270 & 162 \\
\hline January & 221 & 254 & 87 & 894 & 248 & 172 \\
\hline February & 221 & 270 & 84 & 853 & 281 & 133 \\
\hline March & 225 & 254 & 143 & 920 & 327 & 248 \\
\hline April & 230 & 286 & 119 & 920 & 326 & 240 \\
\hline TOTAL & 1,962 & 2,358 & 818 & 8,138 & 3,005 & 1,612 \\
\hline
\end{tabular}

Referral to Other Agencies.

\begin{tabular}{l|c|c|c}
\hline $\begin{array}{l}\text { Year } \\
\text { Month }\end{array}$ & Louisville & Indianapolis & Dayton \\
\hline 1943 & 37 & 15 & 28 \\
July & 47 & 28 & 22 \\
August & 48 & 26 & 27 \\
September & 67 & 11 & 32 \\
October & 69 & 10 & 19 \\
Nowember & 35 & 8 & 11 \\
December & & 9 & 16 \\
l944 & 84 & 9 & 6 \\
January & 64 & 11 & 29 \\
February & 236 & 8 & 19 \\
March & 118 & 135 & 209 \\
April & 805 & & \\
TOTAL & & & \\
\hline
\end{tabular}




\section{CONCLUSION}




\section{$\underline{\mathrm{C}} \underline{O} \underline{\mathbb{N}} \underline{\mathrm{C}} \underline{\mathrm{L}} \underline{\mathrm{S}} \underline{\mathrm{I}} \underline{\mathrm{O}} \mathbb{N}$}

The author has no doubt of the value of the Louisville Home Service program, from its inception in 1917, through the years which followed. Such shattering events as World War I and World War II cannot fail but produce a long-continuing need for services to the hordes of men who have fought, and to their dependents. It is difficult to imagine how these people who turned to Home Service for help could have managed without the assistance which they received.

That the records of Home Service during the peacetime years of the 20 's and 30 's are so scant, is perhaps an indication of some weakness in the program. Also an indication of a possible weakess is the failure of the agency during these years to institute any form of self-evaluation. It is known that emphasis was not laid on case-work services to the applicants, but the great bulk of the work was in assisting them with obtaining benefits for which they believed themselves eligible, and with necessary assistance until such benefits were obtained or denied. However, those services too were necessary to the community, and are a justification of the program.

Since 1940, and the outbreak of World War II, Home Service has done an almost unbelievable job of expansion. There has been excellent cormunity participation. In interpretation of national policies, the direction of the program has been towards a liberal and broad interpretation. The interests of the applicant have been 
placed foremost whenever possible. Community resources have not been neglected, and the agency has taken its place as a leader in working towards improvement of these resources. Louisville Home Service has an understanding of its present and future responsibility towards the veteran of World War II, and is preparing to meet this responsibility.

The present program seems to be a sound one, and if the years following World War I can be used as an indication, the Louisville Home Service progrem will be needed for many years to come. 
APPENDIX 
THE AMERICAN NATIONAL RED CROSS

By-Lews of the Louisville, (Kentucky) Chapter

\section{I.}

The name of this chapter shall be the Louisville (Kentucky) Chapter of the American National Red Cross.

II.

The purpose of this Chapter shall be to act locally for the American National Red Cross in accordance with the Chapter and By-Laws of the National Organization, and in conformity with such policies and regulations as the Central Committee of the American National Red Cross or its duly authorized agents may from time establish.

\section{JURISDICTION}

The territory to be included within the jurisdiction of this Chapter shall be Louisville and Jefferson County, Kentucky, this jurisdiction to be subject to such changes as may be made by the Central Committee or its duly authorized representatives.

\section{OFFICE}

The Headquarters and principal office of this Chapter shall be in the City of Louisville, State of Kentucky.

\section{MEMBERSHIP}

All members of the American National Red Cross residing within the jurisdiction of this Chapter shall be members of this Chapter, provided that for reasons deemed satisfactory to it, the Bxecutive Committee of this Chapter may at any time terminate any membership in the Chapter by giving written notice to the member concerned. Payment of dues by annual, oontributing, sustaining, and supporting members shall entitle them to membership for one year. Life and patron members shall be members of this Chapter as long as they reside within its jurisdiction. 


\section{CHAPTER MEETINGS}

The Chapter shall hold a meeting annually on the second Tuesday in January of each year beginning with the year 1939 at an hour and place to be fixed by the board of directors, for the purpose of electing a board of directors, for the consideration of reports and for the transaction of such other business as may properly come before the meeting.

Notice of the annual meeting of the Chapter shall be published in at least one paper in the City of Louisville, Kentucky, at least ten (10) days prior to the date of the meeting, in a newspaper of general circulation in the territory included within the jurisdiction of the Chapter, such notice to set forth that every person within the territory of the Chapter who has paid Red Cross membership dues within a year or who is a life or patron member is a member of the Chapter and is expected to attend and note at the meeting.

Special meetings may be held at such times and upon such notice as the board of direotors of the Chapter may prescribe.

Fifteen members shall constitute a quorum at the annual or at any special meeting of the Chapter.

\section{BOARD OF DIRECTORS}

All power of government, direction and management conferred upon the Chapter by the Central Committee at Washington, except as hereinafter provided and not inconsistent with the provision of these by-laws, shall be lodged in the Board of Dirootors.

The Board of Directors shall consist of 36 members.

The remaining 36 members of the Board shall be divided into three classes of 12 each.

The Mayor of the City of Louisville, the President of the Louisville Board of Trade and the President of the Jefferson County Medical Society shall be ex-officio members of the Board.

At the annual meeting of the chapter held in the year 1938, said 36 members shall be elected, 12 to serve until the annual meeting in 1939; 12 to serve until the annual meeting in 1940 ; and 12 to serve until the annual meeting in 1941.

At the annual meeting of the Chapter in the year 1939 and at each annual meeting thereafter, 12 Directors $s$ hall be elected to serve for the term of three years. 
All Directors shall hold office until their successors are elected.

Twelve members shall constitute a quorum at all meetings of the Board of Directors.

\section{EXECUTIVE COMITTEE}

The Executive Comittee of the Chapter shall consist of nine members, in addition to the Chairman, Vice-Chairman, Secretary and Treasurer of the Chapter, who shall serve as ex-officio members wi th the power to vote.

Immediately following the annual meeting in the year 1938, the Board of Directors shall appoint from their members nine members of the Exeoutire Comitter, three each to serve respectively for one, two and three years. Annually thereafter the Board of Directors shall appoint from their members three persons to serve for the term of three years.

No member of the Executive Committee shall be eligible for reappointment for the period of one year following the expiration of the term for which such member was appointed.

Retiring members of the Executive Committee shall be eligible for election to the Board of Directors.

The Executive Committee shall have charge of the affairs of the Chapter in the interim botween sessions of the Board of the Directors.

Five members shall constitute a quorm at all meetings of the Executive Comittee.

\section{OFFICERS}

The officers of the Chapter shall consist of a Chairman, a Vice-Chairman, a Secretary and a Treasurer and such other officers as the Directors may determine. Officers shall be elected annually by the Board of Directors. Excepting the Chairman and Vice-Chairman, the officers need not be elected from the membership of the Board, but if they are not, they shall become ex-officio Board members immediately upon their election as officers.

The Chairman of the Chapter shall be a member of the Board of Directors, also serve as Chairman of the Board of Directors and ex-officio Chairman of the Executive Committee. He shall perform the duties usually performed by the chier executive officer of an organization and such other duties as may be assigned by the Board of Directors. 
The Vice-Chairman of the Chapter shall also serve as Vice-Chairman of the Board of Directors and ex-officio ViceChairman of the Executive Committee. He shall have all the powers and duties of the Chaiman in the absence or disability of the latter, and shall perform such other duties as may be assigned by the Chairman or the Board of Directors.

The Secretary of the Chapter shall be Secretary of the Board of Directors and ex-officio Secretary of the Executive Committee. He shall record and preserve the minutes of all meetings of the Chapter, of the Board of Directors and of the Executive Committee, shall issue notices of the meetings of the Chapter, the Board of Directors and of the Executive Committee, shall keep the roll of members, shall send to Headquarters the names of the Directors, and the Executive Committee and of the officers elected each year and shall maintain the necessary documents of record for the Chapter transmitting to the Board of Directors, the Executive Committee and the National Organization such reports as may be required by the by-laws.

The Treasurer of the Chapter shall be ex-officio member of the Board of Directors and ex-officio member of the Executive Committee. He shall receive and disburse funds received by or contributed to the Chapter, shall keep proper books of account, and shall from time to time account to and make such reports to the American National Red Cross thragh the proper office as its regulations, rulings and practices may prescribe.

\section{BRANCHES AND AUXILIARIES}

Branches and auxiliaries of the Chapter may be established only by action of the Board of Directors.

\section{CONDITTEES}

The Board of Directors shall have the power to appoint and delegate power to such committees as it may consider necessary and desirable for the proper management of the affairs of the Chapter, to fix the powers and duties of such committees, to increase or reduce the membership of said cormittees and to terminate the existence of any such committee.

\section{FUNDS}

All money paid to the Chapter shall be kept in such depository or depositories as are designated by the Board of Directors and shall be disbursed by instruments signed and countersigned in such a manner as the Board of Directors may determine. 


\section{ACCOUNTS AND AUDITS}

The accounts of the Chapter shall be kept in such manner as to show readily at all times the exact financial condition of the Chapter, the sources of all receipts and purposes of all disbursements, and shall at all times be accessible to the Central Committee of the American National Red Cross or its duly authorized agents.

The accounts shall be audited at least once each year by a competent accountant who is not an officer of the Chapter and a copy of such audit shall be transmitted to the National Organization; such audit to be accompanied by bank certificates verifying the amounts reported as on deposit and by a detailed certified list of all securities and investments held by the Chapter.

\section{MINUTES AND OTHER RECORDS}

The minutes of the meetings of the Chapter, the Board of Directors, the Executive Committee and all committees, the letters and circulars of instruction received from the National Organization, the files of official correspondence, the Home Service oase files, the Red Cross Handbook of Instruction and other like reference material supplied by the National Organization, and the records of membership and of enroliment for service, except such as must be sent to the National Organization, shall be the property of the Chapter and shall be in the custody of the secretary and shall at all times be accessible to the Central Committee of the American National Red Cross or its duly authorized agents. None of the aforementioned minutes, files, records or reference material can be transferred to another agency nor become the property of any former worker upon leaving the employ of the Chapter.

\section{DELBGATES TO NATIONAL ANNUAL MEETING}

The Board of Directors shall have power to appoint delegates to represent the Chapter at the annual meeting of the American Red Cross and in the event that the Board of Direotors does not appoint such delegates, they may be appointed by the Chairman of the Chapter.

\section{NOTICE OF MEETING}

Written or printed notices of all meetings of the Board of Directors and the Executive Committee shall be mailed to the last known post office address of each member of the Board of Directors and the Executive Comittee. 


\section{VACANCIES}

The Board of Directors shall have power to fill vacancies in its own number, in the Executive Committeo or among the officers of the Chapter.

\section{MEETINGS}

The Board of Directors shall meet on the call of the Chairman or upon the written request of not less than twolve.

The Executive Committee shall meet monthly except in the months of July and August.

Spesial meetings of the Executive Comitter may be called by the Chairman or upon written request of not less than four members.

\section{EMLAM}

It shall be the duty of the officers and the Board of Directors to prevent the improper use of the name of the Red Cross and its insigaia.

\section{AMENDMENT}

The se by-laws may be amended at any meeting of the Chapter, at which a quorum is present, by a majority vote of those present, or may be amended by unanimous vote of the members of the Board of Directors present at a meeting specially cal led for that purpose, at which a quorum is present, provided, however, that written notice of all amendments to be proposed must first be given at least five days prior to any such Chapter or Board of Directors meeting.

\section{DISSOLUTION OF CHAPTER}

This Chapter may be dissolved by action of the Central Comittee of the American National Red Cross or by voluntary vate of three-fourths of the members of the Chapter present at a meeting called for that purpose. Thirty days' notice of the Chapter meeting at which dissolution is to be considered shell be given. If dissolved by its own vote, the retiring chairman or secretary shall notify Headquarters of such action, but such voluntary dissolution shall only take effect upon approval by the Vice-Chairmen in Charge of Domestic Operations and certification by him to the Central Comittee that such Chapter has discharged off of its financial obligations pursuant to its by-laws. 
LOUISVILLE CHAPTER, AMERICAN RED CROSS, FAMILY BUDGET

Case Name

Address
Date Budget made

Number covered by Budget

A. FAMILY'S PRESENT MONTHLY EXPENSES B. FAMILY'S PRESENT MONTHLY INCOME

C. FAMILY'S EXPECTED INCOME
1. Food (including milk)

2. Shelter (rent or ownership)

3. Clothing...........\$ \$

4. Fuel (Heating \& Cooking)

5. Lights..............

6. Water.

7. Refrigeration

8. Personal Incidentals..

9. Household Supplies....

$\$$

10. Transportation........

11. Insurance...........

12. Education.............

13. Other

14.

15. Total Monthly Expenses

BMERGENCY FINANCIAL NEEDS

Amount

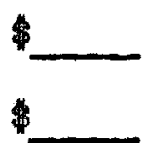

(A-15 minus $B-8$ or $B-8$ minus $A-15$ )

OTHER RESOURCES

War Bonds ....

Savings....... Cash on hand. Other..........

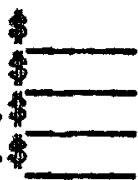

OUTSTANDING DEBTS

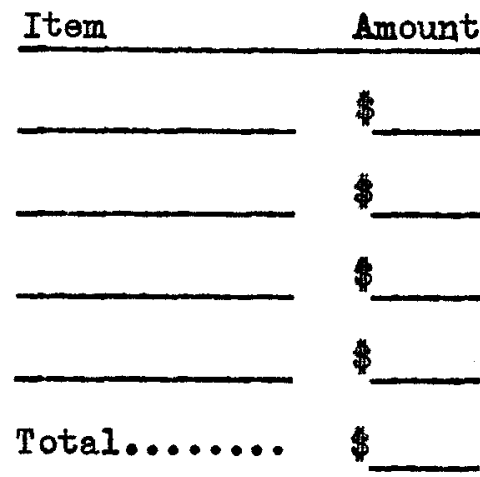

1. Wages and Salaries 1.

2. Allotments

2. $\$$

3. Compensation Pension

3.

4. Boarders \& Lodgers

4.

5. Insurance

5.

6. Other

$\$$

6.

7. Other

$\$$

7.

8. Total Monthly Income

8.

9. Present deficit or excess

9.

Total Expected income \$

Expected deficit or excess (A-15 minus $\mathrm{C}-8$ or minus $A-15$ )

Creditor

smount

Date Incurred

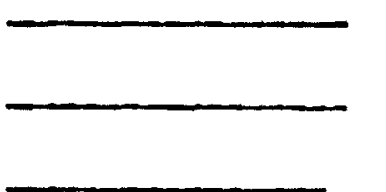

$\$$

Total in Debts..

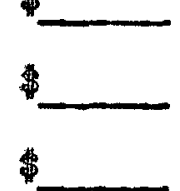

$\$$ 


\section{AMERICAN RED CROSS \\ $\frac{\text { Outline of Case Record }}{\text { For Disaster Cases }}$}

1. Date of first home interview.

2. History

A. Economic and social history of family.

1. Length of residence in the community.

2. Place of birth.

3. Citizenship status.

4. Past work history.

5. Service, or prospects of service, of eny member of the family in the armed forces.

6. Educational background.

B. Family's outside obligations or responsibilities.

C. Unusual experience due to the disaster.

D. Other factors contributing to social and economic status of fomily.

3. Health.

A. Disaster-caused death, injuries, or illness and circumstances under which they occurred.

B. Predisaster health problems of all members, notice special conditions which will affect the fomily's ability to recover from the disaster.

C. Physician's verification of such conditions.

D. Medical Record - Hospital or Home Case (Form 2063). Include this if nurse visited case.

4. Disaster Losses. List rach building separately, beginning with home,

A. Real Property - Describe damage as "Slight,"

"Extensive," or "Total." Indicate amount of "slight" or "extensive" damage and give building adviser's estimate on Building and Repair Estimate (Form 1412). If disaster was flood, give depth of water and time it stood in building.

1. If family rents property, state "Renter" and give brief description of living quarters and damage. State amount of rent. 
2. If family owas property, also, state,

a. Number of stories and dimensions.

b. Whether building is freme, boxed, weatherboarded, brick, peinted, etc.

c. Number of rooms used as living quarters.

d. Type of foundation.

$\theta$. Number of porches and size of each.

f. Number of flues and fireplaces.

g. Type of floors.

h. Finish of walls.

i. Type of roof.

\section{Bo Personal Property}

1. Household Goods

a. List of rooms which contained damage or lost furniture.

b. Type of furniture and approximate date of purchase.

c. Add Household Furnishings List (Form 2072) giving articles lost.

2. Food. List items lost and give estimated value.

3. Clothing - Give brief statement of type and amount damaged.

4. Stock - equipment and tools - List and give value of destroyed or damaged equipment with estimated cost to repair. Verify.

5. Automobile or truck - Give make, date of purchase, and whether usable.

6. Livestock and poultry.

a. Kind and number injured or lost.

b. Purchase price or owner's valuation. Verify.

5. Liabilities. List as pre - or postdisaster.

A. Mortgages, Notes and Liens.

1. State whether mortgages are real estate, chattel, or both.

2. Name and address of holder.

3. Date and original amount in parenthesis, extending amount still due.

4. Date of maturity.

5. Method of payment.

6. Amount of interest and principel.

7. Total amount of mortgages, etc. 
B. Personal Bills - List as pre- or postdisaster.

1. Name of creditor, date, original amount, for what bill was incurred.

2. Extend amount due.

6. Help Receired.

A. List Type of help and amount from -

a. Friends and relatives.

b. DPW or other agencies.

c. Firms or organizations.

B. List Red Cross Warehouse Requisitions (Form 2000B) and Disbursing orders (Form 2050) by date, relief classification, and amount.

7. References. Give name, address, and business affiliation of each reference. His tatement should cover -

A. Verification of losses, indication of need for Red Cross assistance.

B. Recuperative powers.

C. Competence in handling own affairs.

8. Family Plan. This shows the needs of family and its share in meeting them.

A. Means family contemplates using to effect readjustment.

B. Contributions members of family intend to make by cash, credit, labor or other resources.

C. What family asks of Red Cross.

D. Possibility of any member of family joining armed forces.

E. Advisability for applying for a loan.

F. Rersoning behind family's decisions and opinions.

9. Worker's Plan. This is both a diagnosis and a plan for treatment. It may be specific. The relation between the loss and the resulting need and the way in which the family's plan plus the worker's plan must cover the need must be kept clearly in mind.

A. Amount of family's progress in rehabilitation.

B. Their use of their resources.

C. Their general attitude.

D. Statement of disabilities and physical and mental handicaps.

E. Effect of health conditions on economic recovery. 
F. Family Dissension, if any.

G. Local oconomic conditions (chronic unemployment, substandard) Wages, substandard housing affecting children, women or aged.

H. Utilization of community resouroes.

I. Relationship of family's income to regular expenses.

J. Pertinent material regarding mortgages and mortgagor arrangement.

K. Amount of labor family can do, and for which building awards for labor are to be made.

L. Spocial information about $B$ \& $R$ and other classifications of relief.

M. Award plan and recomendations of referral and follow-up.

N. Worker's recommendation for closing the case. 
BIBLIOGRAPHY 


\section{BIBLIOGRAPHY}

Allowance and Allotment Branch, Adjutant General's Office. Monthly Allowances for the Dependents of Soldiers. Washington: Government Printing Office, 1942•

Anderson, Harriet. "Beginning of Red Cross," The Community, February, 1918.

An Introduction to Home Service. A Pamphlet Prepared by the American National Red Cross. Washington, April, 1942.

Annual Report of Home Service, Louisville, Kentucky, Chapter, American Red Cross for the Year of 1918. Louisville, Kentucky, 1919. (Mimeographed).

Annual Report of Home Service, Loui sville, Kentucky, Chapter, Anerican Red Cross for the Year of 1938. Louisville, Kentucky, 1939. (Mimeographed).

Annual Report of Home Service, Louisville, Kentucky, Chapter, American Red Cross for the Year of 1939. Louisville, Kentucky, 1940. (Mimeographed).

Annual Report of Home Service, Louisville, Kentucky, Chapter, American Red Cross for the Year of 1940. Louisville, Kentucky, 1941. (Mimoographed)。

Annual Report of Home Service, Louisville, Kentucky, Chapter, American Red Cross for the Year of 1941. Iouisville, Kentucky, 1942. (Mimeographed)。

Chapter Manual. A Pamphlet Prepared by the American National RedCross. Washington, 1940.

Chapter Manual. An Unpublished Paper Prepared by Home Service, Louisville, Kentucky, Chapter, Anerican Red Cross. Louisville, Kentucky, 1944.

Disaster Relief. Prepared by the American National Red Cross. Washington, 1943. (Mimeographed).

Emergency Maternity and Infant Care. A Folder Prepared by the U.S. Department of Labor, Children's Bureau. Washington, 1944.

Facts About Red Crosso A Pamphlet Prepared by American National Red Cross. Washington, 1943. 
Haugen, Ruth॰ Study of Home Service. August, 1942. (Unpublished).

Highlights Fran Committeo Reports for August, 1943. Prepared by Louisville Chapter, American Red Cross. Louisville, 1943. (Mimeogrop hed).

Highlights of Reports For June, 1943: Prepared by Louisville Chapter, American Red Cross. Louisville, 1943. (Mimeogrep hed).

History and Organization of the Red Crosse Prepared by the Louisville Chapter, Limerican Red Cross, Loui sville, 1943. (Mimeographed).

Home Service Report, September, 1943. Prepared by the Loui sville Chapter, Amerioan Red Cross. Louisville, 1943. (Mimoographed).

Laws Relating to Veterans. Compiled by Elmer A. Lewis (U.S. Govormment Printing office, Kashington, 1944).

Louisville Chapter. Propared by the Louisville Chapter, American Red Cross. Louisville, 1943. (Mimeographed).

Louisville Chapter, American Red Cross, January 1, 1943 to March 31, 1943. Prepared by Louisvilie Chapter, American Red Crose, Louisville, 1943. (Kimeographed).

Louisville, Kentucky, Chapter, American Red Cross Report of Expenditures For Medical and Hospital Care, Calendar Year of January, 1943 through December, 1943. A Report Prepared by the Louisville Chapter, American Red Cross, 1944. (Mimeographed).

Louisville Social Service Directory. Edited by the Louisville Community Council, Louisville, 1921.

Medical and Health Services. Prepared by the American National Red Crosa, Washington, 1943. (Mimeogrephed).

Minutes of Home Service Committee Meetings. Record Kept by Home Service, Louisville Chapter, American Red Cross. From January, 1919 through April, 1944.

Minutes of Executive Committee Meetings. Record Kept by Louisville Chapter, American Red Cross. From April, 1917 through April, 1944.

Minutes of Sub-Comittee on Intake, Council of Social Agencies Meetings. Records Kept by the Council of Social Agencies, Louisville. From August, 1943 through April, 1944. 
Military and Naval Welfare Servioe Department Report. Prepared by Louisville Chapter, American Red Cross. Louisville, 194l. (Mimeographed).

Pickett, Sarah Elizabeth, The American National Red Cross. (The Century Company, New York, 1924).

Planning for the Returning War Veteran. One Program of Discussion at the Hidwest Chest Council Conference. Chicago, 1944 .

Private Bob Thompson and The American Red Cross. Prepared by Eastern Area, Amerioan National Red Cross, Virginia, 1943. (Mimeographed).

Program For Servicemen and Ex-Servicemen and Their Families. Prepared by American Hational Red Cross, Washington, 1943. (Mimeographed).

Preparation of Compensation \& Pension Claims. Prepared by the American National Red Cross, Washington, 1943. (Mimeographed).

Reports of Home Service Department. Monthly Reports Prepared by Louisville Chapter, American Red Cross, Louisville, from January, 1920 through April, 1944. (Mimeographed).

Services to the Armed Forces. Prepared by the American National Red Cross, Washington, 1941. (Mimeographed), 1943.

The Program of the American Red Cross with the Milltary and Naval Sorvices and for Disabled Veterans. Prepared by American National Rod Cross, Washington, 1936.

Volunteer Special Services. Prepared by the American National Red Cross, Washington, 1943. (Mimeographed).

"Volunteer Workers," The Community, May, 1918.

War Service-Hame Service. A Pamphlet Prepared by the American National Red Cross, Washington, 1936.

"What is a Residence Privilege, Anyway?" The Courier-Journal, Louisville, January 23, 1944. Page 6.

What Your Red Cross Dollars Do. Prepared by the American National Red Cross, Washington. (Undated).

When You Go. A Pamphlet Prepared by the American National Red Cross, Washington, 1943. 
Your Louisville Chapter American Red Cross Has: Prepared by the Louisville Chapter, American Red Cross, Louisville, 1941. (Mimeographed). 